Max-Planck-Institut für demografische Forschung

Max Planck Institute for Demographic Research

Konrad-Zuse-Strasse 1 - D-18057 Rostock = Germany = Tel +49 (0) 3812081 - 0 - Fax +49 (0) 3812081 - 202 - www.demogr.mpg.de

MPIDR Working Paper WP 2019-007 I April 2019

\title{
Universal Family Background Effects on Education Across and Within Societies
}

\author{
Michael Grätz I michael.gratz@sofi.su.se \\ Kieron J. Barclay \\ Øyvind N. Wiborg \\ Torkild H. Lyngstad \\ Aleksi Karhula \\ Jani Erola \\ Patrick Präg \\ Thomas Laidley \\ Dalton Conley I dconley@princeton.edu
}

(C) Copyright is held by the authors.

Working papers of the Max Planck Institute for Demographic Research receive only limited review. Views or opinions expressed in working papers are attributable to the authors and do not necessarily reflect those of the Institute. 


\section{Universal Family Background Effects on Education Across and Within Societies}

This version: September 15, 2018

Michael Grätz ${ }^{1,2, ~ *}$, Kieron J. Barclay ${ }^{3,4,5}$, Øyvind N. Wiborg ${ }^{6,7}$, Torkild H. Lyngstad ${ }^{6}$, Aleksi Karhula $^{8}$, Jani Erola ${ }^{8}$, Patrick Präg ${ }^{9}{ }^{10}$, Thomas Laidley ${ }^{11}$, Dalton Conley ${ }^{12, *}$

${ }^{1}$ Swedish Institute for Social Research (SOFI), Stockholm University, Sweden

${ }^{2}$ Institute for Futures Studies, Stockholm, Sweden

${ }^{3}$ Department of Social Policy, London School of Economics and Political Science, United Kingdom

${ }^{4}$ Max Planck Institute for Demographic Research, Rostock, Germany

${ }^{5}$ Department of Sociology, Stockholm University, Stockholm, Sweden

${ }^{6}$ Department of Sociology and Human Geography, University of Oslo, Oslo, Norway

${ }^{7}$ Centre for the Study of Professions (SPS), Oslo Metropolitan University (OsloMet), Oslo, Norway

${ }^{8}$ Department of Social Research, University of Turku, Turku, Finland

${ }^{9}$ Nuffield College, University of Oxford, Oxford, United Kingdom

${ }^{10}$ Department of Sociology, University of Oxford, Oxford, United Kingdom

${ }^{11}$ Department of Sociology, New York University, New York, United States

12 Department of Sociology, Princeton University, Princeton, United States

*Corresponding authors: michael.gratz@sofi.su.se and dconley@princeton.edu. 


\begin{abstract}
The extent to which siblings resemble each other measures the total impact of family background in shaping life outcomes. We study sibling similarity in cognitive skills, school grades, and educational attainment in Finland, Germany, Norway, Sweden, the United Kingdom, and the United States. We also compare sibling similarity by parental education and occupation within these societies. The comparison of sibling correlations across and within societies allows us to characterize the omnibus impact of family background on education across social landscapes. We find similar levels of sibling similarity across social groups. Across countries, we find only small differences. In addition, rankings of countries in sibling resemblance differ across the three educational outcomes we study. We conclude that sibling similarity is largely similar across advanced, industrialized countries and across social groups within societies contrary to theories that suggest large cross-national differences and variation of educational mobility across social groups within societies.
\end{abstract}

\title{
Keywords
}

educational inequality, cross-national comparison, intergenerational transmission, siblings, social mobility 
Social mobility refers to the associations between the educational and socioeconomic outcomes of individuals and their parents. If social mobility is high, then an individual's educational and socioeconomic attainment are largely independent of that of her or his parents, whereas if it is low, most children achieve the same level of education, enter the same occupation, and have a similar income as their parents. In this study we focus on the intergenerational transmission of education, which is of particular relevance in advanced, industrialized societies in which education is an important predictor of life chances. We compare educational mobility across Finland, Germany, Norway, Sweden, the United Kingdom, and the United States, as well as between social groups, in particular by family socioeconomic background, within these countries.

An important school of thought has long held that modernization should lead to greater social mobility within societies; that is in societies which experienced industrialization, educational expansion, urbanization, and greater geographical mobility, the outcomes of children should be determined less by family background (Treiman 1970). In line with this expectation, some authors argue that the degree of social mobility is remarkably similar across societies, despite substantial cross-national differences in educational systems, welfare regimes, and levels of inequality (Clark 2014; Erikson and Goldthorpe 1992; Featherman, Jones, and Hauser 1975; Ishida, Müller, and Ridge 1995; Lipset and Zetterberg 1959; Müller and Karle 1993). Others, however, argue that there remain substantial differences between contemporary societies in their degree of intergenerational mobility and that countries that have greater socioeconomic inequality also have lower social mobility (Andrews and Leigh 2009; Björklund and Jäntti 2009; Corak 2013). Our comparative study, across countries that vary widely on the aforementioned characteristics, sheds important light on the extent to which policy differences between advanced, industrialized countries affect educational mobility. 
In addition, many scholars assert that social mobility varies between social groups within societies. It has long been thought that, due to credit constraints, socioeconomically disadvantaged families experience less intergenerational mobility than socioeconomically advantaged families (Becker and Tomes 1976; Blau and Duncan 1967; Erikson and Goldthorpe 1992; Mazumder 2005). An opposing point of view argues that compensatory parental investment strategies lead to lower social mobility among socioeconomically advantaged families than among socioeconomically disadvantaged families (Conley 2004, 2008; Griliches 1979; Hsin 2012). Our study also tests these claims by estimating educational mobility for different social groups within societies.

We test differences in educational mobility within and across societies using an approach that employs the similarity between siblings in educational outcomes to measure educational mobility. This method allows us to take into account both observed and unobserved aspects of family socioeconomic background (Björklund and Jännti 2012). We use this method to shed light on educational mobility by examining sibling correlations in educational attainment-a cornerstone measure of socioeconomic status - in six countries. Furthermore, we examine sibling similarity in cognitive skills and in school grades. These educational outcomes give us a window into how sibling resemblance develops through early and middle childhood investments (cognitive skills), through the combined role of cognitive and non-cognitive skills as well as through influences of teachers in adolescence (school grades), and through educational aspirations and decision making, expectations, and financing (final educational attainment).

We apply this approach to data on six countries, covering the three main types of welfare states in contemporary, advanced, industrialized societies (Esping-Andersen 1990, 1999). We use survey data on Germany (Socio-Economic Panel Study; SOEP), the United Kingdom 
(Understanding Society), and the United States (Panel Study of Income Dynamics; PSID and National Longitudinal Study of Adolescent to Adult Health; Add Health) as well as register data for Finland, Norway, and Sweden. These data sources allow us to estimate sibling correlations using the highest-quality data available for each country. We make these data comparable by applying the same sample selection criteria, definition of variables, and methods of analysis to all data. The set of countries covers all three types of welfare regimes Esping-Andersen $(1990,1999)$ distinguishes, i.e., using his terminology, conservative (Germany), liberal (United Kingdom, United States), and social democratic (Finland, Norway, Sweden) welfare regimes.

Our approach allows us to give a broad overview over the variation of educational mobility both within and across advanced, industrialized societies. Whilst our analysis is descriptive, it provides important insights into the variation of educational mobility across societies and the mechanisms underlying this cross-national variation by examining variation between social groups within societies.

\section{BACKGROUND AND THEORETICAL CONSIDERATIONS}

\section{Using Sibling Similarity to Measure Universal Family Background Effects}

Most analyses of educational mobility estimate the resemblance in education between parents and offspring (Bradbury et al. 2015; Breen et al. 2009; Ermisch, Jäntti, and Smeeding 2012; Pfeffer 2008; Shavit and Blossfeld 1993). An alternative way to measure the intergenerational openness of a society is to estimate sibling similarity in education. This approach is motivated by the idea that siblings share the same family and immediate environment and that the similarity of siblings can capture, therefore, the universal influence of family background on children's educational outcomes. 
A number of studies estimated educational mobility using sibling correlations and data on Australia, several European countries, and the United States (Anger and Schnitzlein 2017; Benin and Johnson 1984; Björklund and Jännti 2012; Björklund and Salvanes 2011; Conley 2008; Conley and Glauber 2008; Conley, Pfeiffer, and Velez 2007; de Graaf and Huinink 1992; Duncan, Boisjoly, and Harris 2001; Grätz 2018; Hauser and Mossel 1985; Hauser and Wong 1989; Jencks et al. 1972, 1979; Kuo and Hauser 1995; Marks and Mooi-Reci 2016; Mazumder 2008; Nicoletti and Rabe 2013; Olneck 1977; Schnitzlein 2014; Sieben and de Graaf 2001, 2003; Sieben, Huinink, and de Graaf 2001; Teachman 1995; Toka and Dronkers 1996).

There are several advantages associated with using the similarity of siblings in education to measure educational mobility. The use of sibling correlations allows researchers to estimate the effects of observed and unobserved characteristics which are shared by siblings on education. These characteristics include the family environment and the neighborhood. Sibling correlations, therefore, provide omnibus measures of family background that capture the combined effects of shared genetics, common environment, and sibling-reciprocal socialization.

There are three potential disadvantages associated with the use of sibling correlations to measure social mobility. First, a disadvantage of sibling correlations may be that because of their summative nature sibling correlations cannot be decomposed into the different processes of genetic influences, family and neighborhood effects, and inter-sibling influences. We maintain, however, that this is also not the purpose of our descriptive analysis of educational mobility. We understand the similarity between siblings in education as an important descriptive statistic informing us about the variation of educational mobility across contexts.

Second, a further concern with regard to sibling correlations is that siblings may have different experiences within the family. For instance, evidence from family fixed-effects models 
demonstrates that birth order differences lead to inequality in educational outcomes between siblings (Black, Devereux, and Salvanes 2005; Conley et al. 2007; Grätz 2018; Härkönen 2014). These and other sibling-specific influences are not captured by sibling correlations. Further examples include gender and age differences; other factors that produce inequalities between siblings may be unobserved. Sibling correlations in education can, therefore, best be understood as providing lower bound estimates of the total effect of family background on education (Björklund and Jännti 2012).

Third, the identification of educational mobility through sibling correlations focuses necessarily on siblings. The reliance on families with siblings to estimate educational mobility could introduce bias if educational mobility differs between singletons and siblings (Breen and Jonsson 2005). We, however, maintain that most children grow up with siblings, i.e. it is only a small part of the population who does not contribute to the estimation of educational mobility using sibling correlations. In addition, there is no empirical evidence that educational mobility does indeed differ between singletons and siblings.

\section{Variation of Universal Family Background Effects Across Social Groups}

An advantage of employing sibling correlations to measure educational mobility is that they allow us to estimate socioeconomic differences in the transmission of educational advantage across generations. Estimates of educational mobility which focus on the similarity of parents and children (or the similarity of siblings) at the population level do not take into account that educational mobility may vary across social groups within societies. There are, however, strong theoretical reasons to expect such variation. In particular, socioeconomic differences in parental 
investment strategies may lead to variation in sibling similarity, and, hence, educational mobility, by family socioeconomic background.

Two main theories with respect to parents' allocation of resources among siblings can be distinguished. First, theories of parental reinforcement argue that well-resourced parents invest more in the human capital of better endowed children, thereby increasing within-family inequality as compared to socioeconomically disadvantaged parents who face budget constraints in optimally investing into their children (Becker 1991; Becker and Tomes 1976). As a consequence, this theoretical perspective predicts a higher similarity between siblings, and, hence, lower educational mobility, in socioeconomically disadvantaged than in socioeconomically advantaged families.

Second, an alternative model of resource allocation within families argues that parents use resources to compensate for ability differences between siblings (Behrman, Pollak, and Taubman 1982). The ability of parents to implement compensatory strategies is likely to depend on the amount of resources available to them and, therefore, it may mainly be socioeconomically advantaged families who employ compensatory investment strategies that attenuate within-family differences (Conley 2004, 2008; Griliches 1979). In this latter paradigm, with limited resources, disadvantaged families may invest less equitably but more efficiently given budget constraints, thereby exacerbating sibling disparities in abilities by providing more resources to better endowed offspring. This model leads to the opposite prediction than the model assuming reinforcing parental investment strategies. Under compensatory parental investment behavior, we expect a higher similarity between siblings, and, therefore, lower educational mobility, in socioeconomically advantaged than in socioeconomically disadvantaged families.

Evidence on the variation of sibling similarity by family socioeconomic background is mixed and results are so far limited to two countries. Previous research analyzing the variation of sibling 
similarity between social groups in the United States (Conley 2008; Conley and Glauber 2008; Conley et al. 2007) and Germany (Grätz 2018) found no variation in sibling similarity by family socioeconomic background with respect to cognitive skills and educational attainment. However, Conley and Glauber (2008) found higher levels of sibling resemblance in earnings and household income in the United States for siblings from socioeconomically advantaged families compared with siblings from socioeconomically disadvantaged families. In addition, Conley et al. (2007) in the United States and Anger and Schnitzlein (2017) in Germany found a higher sibling similarity in non-cognitive skills in socioeconomically advantaged families than in socioeconomically disadvantaged families. The variation of sibling similarity by family socioeconomic background has never been systematically investigated across countries. The present study aims to fill this gap by examining sibling similarity in education in a comparative perspective. Such a study is important as there are many theoretical reasons to expect cross-national variation in sibling similarity by family background, as we detail in the next section.

In addition to studies analyzing socioeconomic differences in sibling similarity, there are a number of studies analyzing the underlying mechanism which is supposed to bring about differences in sibling similarity, i.e. socioeconomic differences in parental responses to birth endowments or early abilities, directly. We are aware of three empirical studies comparing the allocation of parental investments between siblings or twins to test whether parents' reinforcing or compensatory responses to ability differences between their offspring vary by family socioeconomic background. These three studies used data on the United States but led to contradictory results. In line with the compensatory parental investment model, Hsin (2012) and Restrepo (2016) found compensatory parental responses to birth weight differences between siblings in socioeconomically advantaged and reinforcing behavior in socioeconomically 
disadvantaged families. Contrary to these results, however, Grätz and Torche (2016) found no parental responses to birth weight differences between twins and reinforcing parental responses to twin differences in early abilities concentrated in socioeconomically advantaged families. Due to these contradictory results and the lack of studies investigating socioeconomic differences in parental responses to ability differences between twins or siblings in other countries than the United States, it is an open empirical question whether and when sibling similarity in education varies by family socioeconomic background.

\section{Variation of Universal Family Background Effects Across Societies}

A central question in research on educational mobility is whether and how much the intergenerational transmission of educational advantage varies across countries (Breen and Jonsson 2005). Institutionalist theories argue that differences in educational institutions lead to variation in the degree of educational mobility across countries (Pfeffer 2008; van de Werfhorst 2015). Robust evidence on causal influences of educational institutions on educational mobility is, however, difficult to achieve. Descriptive comparisons of educational mobility across countries cannot identify the factors bringing about cross-country variation in educational mobility as countries differ in more aspects from each other than it can be controlled for (Torche 2015). The analysis we present in this paper falls into this category. We do not argue, therefore, that our analysis identifies factors influencing educational mobility. However, we believe it is important to provide descriptive evidence on the variation of educational mobility across countries. Our analysis reports descriptive results demonstrating the variation of educational mobility across the three main types of welfare states that can be found in advanced, industrialized countries (EspingAndersen 1990). 
A number of previous studied analyzed cross-country variation in educational mobility. Table 1 gives an overview over studies which estimated cross-country differences in educational mobility. The table reports how these studies ranked different countries in terms of educational mobility.

\section{[TABLE 1 ABOUT HERE]}

The comparison of the different studies shows that there is no unambiguous ranking of countries according to their level of educational mobility. This conclusion was already drawn in an older review of studies on educational mobility by Breen and Jonsson (2005). It is, therefore, interesting to see how the rankings of countries we obtain with our approach compare to rankings obtained by previous research which applied different methodologies and data sets to study educational mobility.

We contribute to research on the cross-country variation in educational mobility by providing estimates of country differences in sibling similarity for three educational outcomes (cognitive skills, school grades, and final educational attainment) using high-quality data from administrative registers and nationally representative surveys with large sample sizes. An important innovation of our study, compared to previous research, is that we not only analyze cross-country differences in educational mobility but that we also test whether the variation of educational mobility (i.e., sibling resemblance) across social groups varies across countries. Thus, this study tests not only if educational mobility varies across societies but also whether the underlying pattern of inequality in educational mobility varies across countries. 
We expect both sibling similarity at the population level and differences in sibling similarity between social groups to vary across countries. Following the literature connecting income inequality and income mobility (Andrews and Leigh 2009; Björklund and Jäntti 2009; Corak 2013), we expect a higher sibling similarity in education in countries with more income inequality and less developed welfare states. We expect this to be accompanied by a higher similarity of siblings in socioeconomically advantaged families in these countries (Conley 2004, 2008; Griliches 1979). The alternative expectation is no or only little variation in educational mobility across countries, which would indicate that sibling similarity in education is mainly due to processes at the family-level which are similar across countries and not strongly affected by variation in the policy landscape (Clark 2014).

We selected a sample of advanced, industrialized societies that vary in their degree of inequality, extensiveness of the social safety net, and institutional arrangements of their educational systems: Finland, Germany, Norway, Sweden, the United Kingdom, and the United States. These countries represent the liberal (United Kingdom and United States), conservative (Germany), and social democratic (Finland, Norway, and Sweden) welfare regimes in EspingAndersen's $(1990,1999)$ influential terminology. The differences in welfare regimes are reflected in the different education systems that can be found in these countries. The Scandinavian social democratic countries have inclusive education systems in which pupils learn together for a long time, an extensive amount of public child care, and tuition-free universities. Germany's education system is characterized by early tracking between schools and Germany has a lack of early child care facilities. The United States have a high level of ability-tracking within schools. In the United Kingdom, pupils are tracked in the public school system at a comparatively late age (age 16) but there is a large private school sector to which upper class families often send their children. The 
United States and the United Kingdom also stand out with their high levels of tuition fees at the university level. These fees are especially high at the most prestigious universities.

Finally, the six countries differ in terms of income inequality. According to the World Bank, Germany’s Gini coefficient, measuring income inequality, was 31.7 in 2015, Finland's 27.1, Norway's 27.5, Sweden's 29.2, the United Kingdom's 33.2, and the United States 41.5 (in 2016) (World Bank 2018). For all these reasons, the countries we analyze vary widely in their institutional structures which may lead to cross-country differences in the overall amount of educational mobility and in the variation of educational mobility between social groups within societies.

\section{DATA AND METHODS}

\section{Data}

We use survey data in Germany, the United Kingdom, and the United States. The German data come from the German Socio-Economic Panel Study (SOEP) (SOEP 2016; Goebel et al. 2018). For the United Kingdom, the United Kingdom Household Longitudinal Study (Understanding Society) is used (University of Essex, Institute for Social and Economic Research, and NatCen Social Research 2016). For the United States, we use the Panel Study of Income Dynamics (PSID) (PSID 2016) and the National Longitudinal Study of Adolescent to Adult Health (Add Health) (Harris 2009). Finland, Norway, and Sweden are analyzed using data from registers from the specific countries. We undertake extensive efforts to harmonize the data and variables as good as possible across countries. We limit the discussion of data sets and the construction of variables in the manuscript to the most necessary elements. Full details on the data sources and the construction 
of variables within each country are provided in the Online Supplement, Appendix A. Details on the Specific Data Sets.

\section{Variables}

We measure three educational outcomes, harmonized across the different data sets: cognitive skills, school grades, and final educational attainment. Not all outcomes are available for all countries, but we have information available on each outcome for at least three countries. Table 2 gives an overview over the sample sizes used to obtain the estimates of sibling similarity for each outcome in each country.

\section{[TABLE 2 ABOUT HERE]}

Cognitive skills are measured based on different tests that aim to measure the intellectual development of respondents. These tests were conducted as part of the survey in case of the PSID, Add Health, and the SOEP. Cognitive skills in the Norwegian and Swedish data refer to military conscription tests. Therefore, in Norway and Sweden this information is only available for men. ${ }^{1}$ All measures of cognitive skills are standardized within each country. The age at which these cognitive skills are measured varies between 16-17 (Germany), 17-20 (Norway, Sweden), and 318 (United States).

We use school grades to construct in each country a measure of grade point sum or Grade Point Average (GPA). We standardize these measures within each country. Children are between ages 14 and 18 in the United States and between ages 16 and 17 in the remaining countries at the time school grades are measured. 
Finally we study final educational attainment. This is a continuous variable which is based on years of education. Respondents are at least 25 years old when their final educational attainment is measured.

Table 3 presents the age and cohorts for which these variables are measured in each country.

\section{[TABLE 3 ABOUT HERE]}

In order to estimate the variation of sibling similarity by family socioeconomic background we distinguish between a low and a high social origin based on father's education, mother's education, and parental occupation. Father's and mother's education depend on the highest educational degree obtained by either parent. We identify in each country a major educational cutoff point which defines a high and a low level of education for the father and the mother. Parental occupation refers to whether the highest level of occupation of either parent is in a professional (high parental occupation) or in a non-professional (low parental occupation) position. In the Online Supplement, we also report separate results by maternal and paternal occupation.

\section{Analytical Strategy}

We measures sibling correlations using the intraclass correlation coefficients (ICC) of multilevel models in which respondents (i) are nested within families (j) (Conley et al. 2007; Conley and Glauber 2008; Mazumder 2008; Schnitzlein 2014). The estimated models with outcome $\mathrm{y}_{\mathrm{ij}}$ can be written as:

$$
\mathrm{y}_{\mathrm{ij}}=\beta \mathrm{X}_{\mathrm{ij}}+\varepsilon_{\mathrm{ij}}
$$


with $\mathrm{X}_{\mathrm{ij}}$ being the vector of control variables. Since we are purely interested in the intraclass correlations, we estimate empty models without any control variables.

The residual $\varepsilon_{\mathrm{ij}}$ can be decomposed into family-specific and individual-specific components under the assumption that the covariance between these two parts is zero:

$$
\varepsilon_{\mathrm{ij}}=\mathrm{aj}_{\mathrm{j}}+\mathrm{b}_{\mathrm{ij}}
$$

The intraclass correlation coefficients (ICC) $\rho$ of these models are the sibling correlations. The ICC is given by the following relation of the variances:

$$
\rho=\sigma_{\mathrm{a}}^{2} /\left(\sigma_{\mathrm{a}}^{2}+\sigma_{\mathrm{b}}^{2}\right)
$$

We estimated these models via restricted maximum likelihood estimation (REML) (Mazumder 2008; Schnitzlein 2014). The standard errors were estimated using the delta method. We report figures summarizing our main results below. The full results, including the precise point estimates and the corresponding standard errors, are reported in Tables S1 to S3 in the Online Supplement. The confidence intervals reported in the figures below were obtained by transforming the normal-based confidence intervals using the logit function so that the lower and the upper bound are limited to vary between 0 and $1 .^{2}$ All analyses were conducted using the xtmixed or mixed command in recent versions (12 to 14) of Stata.

We included singletons in the estimation of the main models. We tested the robustness of our estimates to excluding singletons and obtained nearly identical results estimating models on 
samples including only respondents with at least one sibling with valid information in the data. These results are reported in Tables S4 to S6 in the Online Supplement.

We tested whether the sibling correlations are statistically significantly different across countries as well as whether the sibling correlations are statistically significantly different across social groups within countries using two-tailed tests. Before conducting these tests we applied Fisher's z-transformation to the sibling correlations. We tested differences between countries by comparing the z-transformed sibling correlation in a country to the sample-size-weighted average of the z-transformed sibling correlations in all other countries. We refer to these significance tests in the manuscript and report all significance tests in Tables S1 to S6 in the Online Supplement.

\section{RESULTS}

We summarize our results in three figures. Each figure refers to one of the three educational outcomes. Figure 1 reports sibling correlations and their variation by family socioeconomic background as well as between countries with respect to cognitive skills. Figure 2 shows sibling correlations in school grades. Finally, Figure 3 presents our estimates of sibling resemblance in final educational attainment (i.e. years of schooling). The estimates on which these figures are based are fully reported in Tables S1 to S3 in the Online Supplement.

The first column in each figure reports the population-level estimate of sibling similarity in each country. In most cases the sibling correlation for each country is statistically significantly different from the weighted average of the sibling correlations in the other countries (significance tests are reported in the Online Supplement, Tables S1 to S3). However, the size of the differences in the sibling correlations between countries are rather small, suggesting that most of the intergenerational transmission of education is constant across countries. 
[FIGURE 1 ABOUT HERE]

Differences in sibling similarity across countries are smaller for cognitive skills and school grades than for final educational attainment (although we have information on fewer countries for these outcomes). In addition, the ranking of countries in terms of educational mobility measured by siblings correlations differs depending on whether we analyze cognitive skills or school grades. The results for cognitive skills show a higher sibling similarity, and, hence, lower educational mobility, in the United States than in Germany, Norway, and Sweden. The largest difference in sibling correlations is 0.12 ( 0.45 in Norway and 0.57 in the United States [PSID]).

\section{[FIGURE 2 ABOUT HERE]}

Contrary to the results for cognitive skills, sibling similarity in school grades is lower in the United States than in Norway and in Sweden. The largest difference in sibling correlations in school grades is 0.10 (0.42 in the United States and 0.52 in Sweden). Hence, these findings suggest that educational mobility in school grades is slightly higher in the United States than in Sweden and in Norway.

[FIGURE 3 ABOUT HERE]

The cross-country variation in sibling correlations is more pronounced in final educational attainment than in cognitive skills and in school grades. The correlation between siblings in 
educational attainment is comparatively high in the United States $(0.51)$ and in Germany $(0.51)$ and comparatively low in Finland (0.36), Norway (0.41), Sweden (0.44), and the United Kingdom (0.42). Overall, these country differences are, however, small. It is also interesting to note that the difference between Finland and Sweden, measuring the variation among the Nordic countries, is larger than the difference between Sweden and the two least mobile societies in our sample (Germany and the United States).

Analyzing variation in sibling similarity between social groups allows us to explore the patterns underlying sibling similarity at the population level and to better understand cross-country differences. Our cross-country comparisons showed that sibling similarity in final educational attainment at the population level was higher in Germany and in the United States than in the Nordic countries and in the United Kingdom. The following analysis tests whether these country differences can be explained by differences in the variation of sibling similarity by family socioeconomic background. Our results contradict this expectation. In all countries there are no, or only very small, differences in sibling similarity between social groups and these differences do not vary across countries as a function of sibling similarity at the population level.

There are several statistically significant differences between social groups for final educational attainment as an outcome variable (for significance tests see Tables S1 to S3 in the Online Supplement). However, only in Finland and Norway differences between social groups are consistently higher in socioeconomically disadvantaged than in socioeconomically advantaged families for father's education, mother's education, and parental occupation. These differences are very small with the largest difference being 0.06 between high and low maternal education in Finland and 0.08 in Norway. We find no evidence for differences by family socioeconomic 
background that are robust to employing different indicators of social origin in Germany, the United Kingdom, Sweden, and the United States.

In no country systematic differences between social groups can be found with respect to cognitive skills. Variation in sibling resemblance by family socioeconomic background in school grades is very small and only in Norway siblings are consistently more similar in socioeconomically disadvantaged than in socioeconomically advantaged families. The largest difference is found for maternal education with sibling similarity being 0.06 higher for children with low educated mothers than for children with highly educated mothers. This is certainly a substantively very small difference. In all other countries, there are no differences in sibling similarity between social origin groups that are robust to applying different indicators of family socioeconomic background. For instance, in the United States, the difference between siblings similarity in school grades in low and high father's education is 0.24 and, hence, larger than in Norway. However, no differences in sibling similarity in school grades by parental occupation are found in the United States. Hence, socioeconomic differences in sibling similarity in school grades are not robust to changing the indicator of social origin in the United States.

In additional analyses we found no systematic variation in sibling similarity by migration background, family size, or maternal age at birth. These findings hold in all countries included in our study. We report these results in Tables S1 to S3 in the Online Supplement. Hence, our finding of limited variation of sibling similarity by family socioeconomic background also applies to parental resources associated with migration background, family size, and maternal age at birth. 


\section{DISCUSSION AND CONCLUSION}

In this study, we have analyzed the similarity of siblings in cognitive skills, school grades, and final educational attainment across different societies and between social groups within societies. Our findings suggest that the intergenerational transmission of education is partially affected by factors that vary at the country level. Differences between countries are larger for final educational attainment than for cognitive skills and for school grades, suggesting that educational attainment is influenced to a larger degree by factors varying between countries than cognitive skills and school grades.

Reducing sibling resemblance in final educational attainment in Germany and the United States (both 0.51$)$ to the level of Finland $(0.36)$ would reduce sibling similarity by 0.15 . This variation shows the largest impact policies and institutions, such as the degree of tracking or the costs of education, possibly can have on educational mobility (Breen et al. 2009; Pfeffer 2008; van de Werfhorst 2015). But there are other possible explanations for differences between countries, for instance, demographic differences could account for the observed variation in educational mobility across countries (Maralani 2013; Mare 2011; Mare and Maralani 2006).

Notwithstanding some variation between countries exists, our study reveals overall a surprisingly high similarity in the level of sibling resemblance across countries. ${ }^{3}$ The largest differences between countries are found for sibling correlations in educational attainment. However, sibling similarity in educational attainment varies only between 0.36 and 0.51 at the population level in the countries we study. These findings show that the largest part of sibling resemblance in education does not vary across countries. If we are interested in explaining why there is such a strong intergenerational transmission of education in advanced, industrialized societies, we have to note that educational mobility is to a large degree similar across countries. 
An additional finding of our study is that countries rank differently depending on whether cognitive skills, school grades, or educational attainment are used to measure education. This finding further complicates the explanation of how institutions affect educational inequality and the role of income inequality in this process (Andrews and Leigh 2009; Björklund and Jännti 2009; Corak 2013; Pfeffer 2008; van de Werfhorst 2015).

Not only do our rankings of countries differ across different measures of education, they are also at odds with the rankings reported by previous research (Bol and van de Werfhorst 2013; Chmielewski and Reardon 2016; Hertz et al. 2008; Pfeffer 2008; Treiman and Yip 1989). Of course, differences in rankings are likely to be due to methodological differences between studies. However, given that each methodological approach has its own advantages and disadvantages, a conservative interpretation of the finding of diverging rankings of countries in terms of educational mobility is that there is no unambiguous ranking of countries according to their levels of educational mobility — a conclusion which supports the claim made by Breen and Jonsson (2005).

With respect to variation in educational mobility across social groups, we found no evidence that sibling similarity in education varies by family socioeconomic background. Our findings are in line with previous research which found no such differences in Germany (Grätz 2018) and the United States (Conley 2008; Conley and Glauber 2008; Conley et al. 2007). We replicate and expand these findings to a plurality of educational outcomes (cognitive skills, school grades, and final educational attainment) and societies (Finland, Germany, Norway, Sweden, the United Kingdom, and the United States). Previous research, however, identified stronger socioeconomic differences in sibling similarity in non-cognitive skills in Germany (Anger and Schnitzlein 2017) and in the United States (Conley et al. 2007) and in occupational outcomes in the United States (Conley and Glauber 2008). Further research is needed to analyze whether these socioeconomic 
differences in sibling similarity in non-cognitive skills and labor market outcomes vary across countries in a systematic way.

Our major finding of a rather high level of similarity in educational mobility across countries leads us to two main conclusions. First, research which analyzes mechanisms bringing about educational inequalities within one country may generalize to other countries given that advanced, industrialized countries show a similar level of educational mobility. Second, factors which vary across countries, such as educational systems and other institutions, are not likely to be the most important factors driving educational mobility. It is more likely that the intergenerational transmission of education is mainly due to factors and processes at the family level which are unlikely to be strongly affected by educational policies. Given that we found no evidence for variation of educational mobility between social groups within countries, these processes are likely to operate in both socioeconomically advantaged and socioeconomically disadvantaged families.

\section{Acknowledgements}

Previous versions of this study were presented at the European Consortium for Sociological Research (ECSR) conference in Tallinn in 2015, at the annual meeting of the Population Association of America (PAA) in Washington, D.C. in 2016, and at the German Socio-Economic Panel Study User Conference in Berlin in 2016. We thank participants at these meetings as well as Tina Baier, Richard Breen, John Ermisch, Fabian Pfeffer, Lindsay Richards, and Elizabeth Washbrook for their comments and suggestions on this study. Access to most data used in this study is restricted. Researchers can apply to access each data set via the specific data providers. We make the do-files underlying our analyses available upon request. Data on Germany used in this publication were made available to us by the German Socio-Economic Panel Study (SOEP) at 
the German Institute for Economic Research (DIW), Berlin. Access to the Swedish register data was supported by the Stockholm University SIMSAM Node for Demographic Research and Swedish Research Council grant 340-2013-5164. Grätz acknowledges funding from the Forskningsrådet om Hälsa, Arbetsliv och Välfärd (Forte) under the grant agreements 2016-07099 and 2017-02047. Barclay was supported by an ERC grant 336475 (COSTPOST) awarded to Mikko Myrskylä. Norwegian register data is used from two sources. The first data set is sponsored and maintained by the Department of Sociology and Human Geography, University of Oslo (PI: Marianne N. Hansen and Arne Mastekaasa). The second data set includes cognitive outcomes, and was prepared for the Research Council of Norway's FINNUT project no. 237831 (PI: Ingrid Sivesind Mehlum). Access to the Finnish register data was provided by Statistics Finland. Erola and Karhula acknowledge funding from the European Research Council (ERC-2013-CoG617965) and the Strategic Research Council at the Suomen Akatemia (Academy of Finland) for the project TITA (293103). Understanding Society is an initiative by the Economic and Social Research Council, with scientific leadership by the Institute for Social and Economic Research, University of Essex, and survey delivery by the National Centre for Social Research and TNS BRMB. This research uses data from Add Health, a program project directed by Kathleen Mullan Harris and designed by J. Richard Udry, Peter S. Bearman, and Kathleen Mullan Harris at the University of North Carolina at Chapel Hill, and funded by grant P01-HD31921 from the Eunice Kennedy Shriver National Institute of Child Health and Human Development, with cooperative funding from 23 other federal agencies and foundations. Special acknowledgment is due Ronald R. Rindfuss and Barbara Entwisle for assistance in the original design. Information on how to obtain the Add Health data files is available on the Add Health website (http://www.cpc.unc.edu/addhealth). No direct support was received from grant P01-HD31921 for 
this analysis. For the Panel Study of Income Dynamics portion of this analysis, we acknowledge the collection of data used in this study as being partly supported by the National Institutes of Health under grant number R01 HD069609 and the National Science Foundation under award number 1157698. Conley and Laidley also acknowledge support from the John D. and Catherine T. MacArthur Foundation: Grant for Research Network on Connected Learning (Grant number 13-105643-000).

\section{ENDNOTES}

1. There is a possibility that estimates for male siblings may be different than for siblings with mixed gender. We can, however, not take into account this possibility as, due to small sample sizes, we cannot estimate models restricted to male siblings in Germany and in the United States.

2. Normal-based confidence intervals are reported in Tables S7 to S12 in the Online Supplement.

3. Because our data are only suitable for examining estimates of educational mobility at the national level, we cannot speak to the geographic variation within countries. While we find that the United States evinces more or less similar levels of educational mobility compared to the other countries in our sample, there may be geographic variation that we cannot account for. Chetty et al. (2014) demonstrated considerable regional variation in income mobility in the United States. We are not aware of similar studies with respect to educational mobility.

\section{REFERENCES}

Andrews, Dan, and Andrew Leigh. 2009. "More Inequality, Less Mobility.” Applied Economics Letters 16:1489-92. 
Anger, Silke, and Daniel D. Schnitzlein. 2017. "Cognitive Skills, Non-Cognitive Skills, and Family Background: Evidence from Sibling Correlations.” Journal of Population Economics 30:591-620.

Becker, Gary S. 1991. A Treatise on the Family. Enlarged Edition. Cambridge, MA: Harvard University Press.

Becker, Gary S., and Nigel Tomes. 1976. "Child Endowments and the Quantity and Quality of Children." Journal of Political Economy 84:S143-62.

Behrman, Jere R., Robert A. Pollak, and Paul Taubman. 1982. "Parental Preferences and Provision for Progeny." Journal of Political Economy 90(1):52-73.

Benin, Mary H., and David R. Johnson. 1984. "Sibling Similarities in Educational Attainment: A Comparison of Like-Sex and Cross-Sex Sibling Pairs." Sociology of Education 57:11-21.

Björklund, Anders, and Markus Jäntti. 2009. "Intergenerational Income Mobility and the Role of Family Background.” Pp. 491-521 in The Oxford Handbook of Economic Inequality, edited by W. Salverda, B. Nolan, and T. M. Smeeding. Oxford: Oxford University Press.

Björklund, Anders, and Markus Jäntti. 2012. "How Important is Family Background for LaborEconomic Outcomes?" Labour Economics 19:465-74.

Björklund, Anders, and Kjell G. Salvanes. 2011. "Education and Family Background: Mechanisms and Policies." Pp. 201-47 in Handbook of the Economics of Education, Volume 3, edited by E. A. Hanushek, S. Machin and L. Woessmann. Amsterdam: Elsevier.

Black, Sandra E., Devereux, Paul J., and Kjell G. Salvanes. 2005. "The More, the Merrier? The Effect of Family Size and Birth Order on Children's Education.” The Quarterly Journal of Economics 120(2):669-700. 
Blau, Peter M., and Otis D. Duncan. 1967. The American Occupational Structure. New York: The Free Press.

Bol, Thijs, and Herman G. van de Werfhorst. 2013. "Educational Systems and the Trade-Off between Labor Market Allocation and Equality of Educational Opportunity." Comparative Education Review 57(2):285-308.

Bradbury, Bruce, Miles Corak, Jane Waldfogel, and Elizabeth Washbrook. 2015. Too Many Children Left Behind: The U.S. Achievement Gap in Comparative Perspective. New York: Russell Sage Foundation.

Breen, Richard, and Jan O. Jonsson. 2005. "Inequality of Opportunity in Comparative Perspective: Recent Research on Educational Attainment and Social Mobility." Annual Review of Sociology 31:223-43.

Breen, Richard, Ruud Luijkx, Walter Müller, and Reinhard Pollak. 2009. "Nonpersistent Inequality in Educational Attainment: Evidence from Eight European Countries.” American Journal of Sociology 114:1475-521.

Chetty, Raj, Nathaniel Hendren, Patrick Kline, and Emmanuel Saez. 2014. "Where is the Land of Opportunity? The Geography of Intergenerational Mobility in the United States.” Quarterly Journal of Economics 129(4):1553-623.

Chmielewski, Anna K., and Sean F. Readon. 2016. "Patterns of Cross-National Variation in the Association between Income and Academic Achievement.” AERA Open 2(3):1-27.

Clark, Gregory. 2014. The Son Also Rises: Surnames and the History of Social Mobility. Princeton, NJ: Princeton University Press.

Conley, Dalton. 2004. The Pecking Order: Which Siblings Succeed and Why. New York: Pantheon Books. 
Conley, Dalton. 2008. "Bringing Sibling Differences In: Enlarging Our Understanding of the Transmission of Advantage in Families.” Pp. 179-200 in Social Class: How Does It Work?, edited by A. Lareau and D. Conley. New York: Russell Sage Foundation.

Conley, Dalton, and Rebecca Glauber. 2008. “All in the Family? Family Composition, Resources, and Sibling Similarity in Socioeconomic Status." Research in Social Stratification and Mobility 26:297-306.

Conley, Dalton, Kathryn M. Pfeiffer, and Melissa Velez. 2007. "Explaining Sibling Differences in Achievement and Behavioral Outcomes: The Importance of Within- and Between-Family Factors." Social Science Research 36:1087-104.

Corak, Miles. 2013. "Income Inequality, Equality of Opportunity, and Intergenerational Mobility." Journal of Economic Perspectives 27:79-102.

de Graaf, Paul, and Johannes Huinink. 1992. "Trends in Measured and Unmeasured Effects of Family Background on Educational Attainment and Occupational Status in the Federal Republic of Germany.” Social Science Research 21:84-112.

Duncan, Greg J., Johanne Boisjoly, and Kathleen M. Harris. 2001. “Sibling, Peer, Neighbor, and Schoolmate Correlations as Indicators of the Importance of Context for Adolescent Development.” Demography 38:437-47.

Erikson, Robert, and John H. Goldthorpe. 1992. The Constant Flux: A Study of Class Mobility in Industrial Societies. Oxford: Clarendon Press.

Ermisch, John, Markus Jäntti, and Timothy Smeeding, Eds. 2012. From Parents to Children: The Intergenerational Transmission of Advantage. New York: Russell Sage Foundation.

Esping-Andersen, Gøsta. 1990. The Three Worlds of Welfare Capitalism. Princeton, NJ: Princeton University Press. 
Esping-Andersen, Gøsta. 1999. Social Foundations of Postindustrial Economies. Oxford: Oxford University Pres.

Featherman, David L., F. Lancaster Jones, and Robert M. Hauser. 1975. “Assumptions of Social Mobility Research in the U.S.: The Case of Occupational Status." Social Science Research 4:329-60.

Goebel, Jan, Markus Grabka, Stefan Liebig, Martin Kroh, David Richter, Carsten Schröder, and Jürgen Schupp. 2018. "The German Socio-Economic Panel (SOEP)." Journal of Economics and Statistics, doi: 10.1515/jbnst-2018-0022.

Grätz, Michael. 2018. "Competition in the Family: Inequality between Siblings and the Intergenerational Transmission of Educational Advantage.” Sociological Science 5:246-69.

Grätz, Michael, and Florencia Torche. 2016. “Compensation or Reinforcement? The Stratification of Parental Responses to Children's Early Ability.” Demography 53(6):1883-904.

Griliches, Zvi. 1979. "Sibling Models and Data in Economics: Beginning of a Survey.” Journal of Population Economics 87(5):S37-64.

Härkönen, Juho. 2014. "Birth Order Effects on Educational Attainment and Educational Transitions in West Germany.” European Sociological Review 30(2):166-79.

Harris, Kathleen M. 2009. The National Longitudinal Study of Adolescent to Adult Health (Add Health), Waves I \& II, 1994-1996; Wave III, 2001-2002; Wave IV, 2007-2009 [machinereadable data file and documentation]. Chapel Hill, NC: Carolina Population Center, University of North Carolina at Chapel Hill. doi: 10.3886/ICPSR27021.v9.

Hauser, Robert M., and Peter A. Mossel. 1985. "Fraternal Resemblance in Educational Attainment and Occupational Status." American Journal of Sociology 91:650-73. 
Hauser, Robert M., and Raymond S.-K. Wong. 1989. "Sibling Resemblance and Intersibling Effects in Educational Attainment." Sociology of Education 62:149-71.

Hertz, Tom, Tamara Jayasundera, Patrizio Piraino, Sibel Selcuk, Nicole Smith, and Alina Verashchagina. 2008. "The Inheritance of Educational Inequality: International Comparisons and Fifty-Year Trends." The B.E. Journal of Economic Analysis and Policy $7(2): 1935-82$.

Hsin, Amy. 2012. "Is Biology Destiny? Birth Weight and Differential Parental Treatment." Demography 49(4):1385-405.

Ishida, Hiroshi, Walter Müller, and John M. Ridge. 1995. "Class Origin, Class Destination, and Education: A Cross-National Study of Ten Industrial Nations." American Journal of Sociology 101(1):145-93.

Jencks, Christopher, Susan Bartlett, Mary Corcoran, James Crouse, David Eaglesfield, Gregory Jackson, Kent McCelland, Peter Mueser, Michael R. Olneck, Joseph Schwartz, Sherry Ward, and Jill Williams. 1979. Who Gets Ahead? The Determinants of Economic Success in America. New York: Basic Books.

Jencks, Christopher, Marshall Smith, Henry Acland, Mary Jo Bane, David Cohen, Herbert Gintis, Barbara Heyns, and Stephan Michelson. 1972. Inequality: A Reassessment of the Effect of Family and Schooling in America. New York: Basic Books.

Kuo, Hsiang-Hui D., and Robert M. Hauser. 1995. "Trends in Family Effects on the Education of Black and White Brothers." Sociology of Education 68:136-60.

Lipset, Seymour M., and Hans L. Zetterberg. 1959. "Social Mobility in Industrial Societies.” Pp. 11-75 in Social Mobility in Industrial Society, edited by S. M. Lipset and R. Bendix. Berkeley, CA: University of California Press. 
Maralani, Vida. 2013. "The Demography of Social Mobility: Black-White Differences in the Process of Educational Reproduction.” American Journal of Sociology 118:1509-58.

Mare, Robert D. 2011. “A Multigenerational View of Inequality.” Demography 48:1-23.

Mare, Robert D., and Vida Maralani. 2006. “The Intergenerational Effects of Changes in Women's Educational Attainments.” American Sociological Review 71:542-64.

Marks, Gary N., and Irma Mooi-Reci. 2016. "The Declining Influence of Family Background on Educational Attainment in Australia: The Role of Measured and Unmeasured Influences." Social Science Research 55:171-85.

Mazumder, Bhashkar. 2005. "Fortunate Sons: New Estimates of Intergenerational Mobility in the United States using Social Security Data." Review of Economics and Statistics 87:235-55.

Mazumder, Bhashkar. 2008. "Sibling Similarities and Economic Inequality in the US." Journal of Population Economics 21:685-701.

Müller, Walter, and Wolfgang Karle. 1993. "Social Selection in Educational Systems in Europe.” European Sociological Review 9(1):1-23.

Nicoletti, Cheti, and Birgitta Rabe. 2013. "Inequality in Pupils' Test Scores: How Much do Family, Sibling Type and Neigbourhood Matter?" Economica 80:197-218.

Olneck, Michael R. 1977. "On the Use of Sibling Data to Estimate the Effects of Family Background, Cognitive Skills, and Schooling: Results from the Kalamazoo Brothers Study.” Pp. 125-62 in Kinometrics: Determinants of Socioeconomic Success within and between Families, edited by P. Taubman. Amsterdam.

Pfeffer, Fabian. 2008. "Persistent Inequality in Educational Attainment and its Institutional Context.” European Sociological Review 24:543-65. 
PSID 2016. Panel Study of Income Dynamics, Public Use Dataset. Produced and distributed by the Survey Research Center, Institute for Social Research, University of Michigan, Ann Arbor, MI.

Restrepo, Brandon. 2016. "Parental Investment Responses to a Low Birth Weight Outcome: Who Compensates and Who Reinforces?" Journal of Population Economics 29(4):969-89.

Schnitzlein, Daniel D. 2014. "How Important is the Family? Evidence from Sibling Correlations in Permanent Earnings in the US, Germany and Denmark." Journal of Population Economics 27:69-89.

Shavit, Yossi, and Hans-Peter Blossfeld (Eds.). 1993. Persistent Inequality: Changing Educational Attainment in Thirteen Countries. Boulder, CO: Westview Press.

Sieben, Inge, and Paul de Graaf. 2001. "Testing the Modernization Hypothesis and the Socialist Ideology Hypothesis: A Comparative Sibling Analysis of Educational Attainment and Occupational Status.” British Journal of Sociology 52:441-67.

Sieben, Inge, and Paul de Graaf. 2003. "The Total Impact of the Family on Educational Attainment." European Societies 5:33-68.

Sieben, Inge, Johannes Huinink, and Paul de Graaf. 2001. "Family Background and Sibling Resemblance in Educational Attainment: Trends in the Former FRG, the Former GDR and the Netherlands.” European Sociological Review 17:401-30.

SOEP. 2016. Socio-Economic Panel (SOEP), Data for Years 1984-2014, Version 31.1. doi: 10.5684/soep.v31.1.

Teachman, Jay D. 1995. "Sibling Resemblance and Symmetry in Intellectual Skill.” Sociology of Education 68:205-20. 
Toka, Gabor, and Jaap Dronkers. 1996. "Sibling Resemblance in Educational Attainment, Occupational Prestige, and Wealth in Hungary during the Communist Regime." European Sociological Review 12:251-69.

Treiman, Donald J. 1970. "Industrialization and Social Stratification." Sociological Inquiry 40:207-34.

Treiman, Donald J., and Kam-Bor Yip. 1989. "Educational and Occupational Attainment in 21 Countries.” Pp. 373-94 in Cross-National Research in Sociology, edited by M. L. Kohn. Sage Publications, Newbury Park, CA.

Torche, Florencia. 2015. "Intergenerational Mobility and Equality of Opportunity." European Journal of Sociology 56(3):343-71.

University of Essex, Institute for Social and Economic Research, and NatCen Social Research. 2016. Understanding Society, Waves 1-6, 2009-2015. 8th ed. Essex: UK Data Service. SN: 6614. doi: 10.5255/UKDA-SN-6614-9.

van de Werfhorst, Herman G. 2015. "Institutional Contexts for Socioeconomic Effects on Schooling Outcomes." In Emerging Trends in the Social Sciences, edited by R. A. Scott and S. M. Kosslyn. Wiley, New York, NY. doi: 10.1002/9781118900772.etrds0186.

World Bank. 2018. https://data.worldbank.org/indicator/SI.POV.GINI, last accessed September 6, 2018. 


\section{TABLES}

Table 1. Overview over Previous Research Analyzing Cross-National Variation in Educational Mobility.

\begin{tabular}{|c|c|c|c|}
\hline Study & Data & Method & $\begin{array}{l}\text { Ranking of countries (from most to } \\
\text { least mobile) }\end{array}$ \\
\hline Treiman and Yip (1989) & $\begin{array}{l}\text { Political Action, Scandinavian } \\
\text { Welfare Study, Oxford National } \\
\text { Occupational Mobility Inquiry, } \\
\text { ZUMABUS, Determinants of } \\
\text { Occupational Mobility, National } \\
\text { Labor Force Survey, } 1975 \text { Social } \\
\text { Stratification and Mobility Survey, } \\
\text { Occupational Changes in a } \\
\text { Generation II }\end{array}$ & $\begin{array}{l}\text { Association between father's } \\
\text { education and son's educational } \\
\text { attainment }\end{array}$ & $\begin{array}{l}\text { United States, Ireland, (West) } \\
\text { Germany/ Japan, Norway, Austria, } \\
\text { Finland, England and Wales, Israel, } \\
\text { Netherlands/ Sweden, Italy, and } \\
\text { Denmark }\end{array}$ \\
\hline Treiman and Yip (1989) & $\begin{array}{l}\text { Political Action, Scandinavian } \\
\text { Welfare Study, Oxford National } \\
\text { Occupational Mobility Inquiry, } \\
\text { ZUMABUS, Determinants of } \\
\text { Occupational Mobility, National } \\
\text { Labor Force Survey, } 1975 \text { Social } \\
\text { Stratification and Mobility Survey, } \\
\text { Occupational Changes in a } \\
\text { Generation II }\end{array}$ & $\begin{array}{l}\text { Association between father's } \\
\text { occupation and son's educational } \\
\text { attainment }\end{array}$ & $\begin{array}{l}\text { Denmark, Ireland, Austria/ Italy, } \\
\text { Netherlands, Finland, Israel, (West) } \\
\text { Germany, Norther Ireland, United } \\
\text { States, Sweden, Japan, England and } \\
\text { Wales, and Norway }\end{array}$ \\
\hline Pfeffer (2008) & $\begin{array}{l}\text { International Adult Literacy Survey } \\
\text { (IALS) }\end{array}$ & $\begin{array}{l}\text { Association between parental } \\
\text { education and children's educational } \\
\text { attainment }\end{array}$ & $\begin{array}{l}\text { Finland, Northern Ireland, New } \\
\text { Zealand, Denmark, Great Britain, } \\
\text { United States, Canada, Czech } \\
\text { Republic, Sweden, Poland, Chile, } \\
\text { Ireland, Italy, Norway, Hungary, } \\
\text { Switzerland, Belgium, Germany, and } \\
\text { Slovenia }\end{array}$ \\
\hline Hertz et al. (2008) & $\begin{array}{l}\text { International Adult Literacy Survey } \\
\text { (IALS), International Social Survey } \\
\text { Programme (ISSP) }\end{array}$ & $\begin{array}{l}\text { Association between parental } \\
\text { education and children's educational } \\
\text { attainment }\end{array}$ & $\begin{array}{l}\text { Denmark, Great Britain, Northern } \\
\text { Ireland, Finland, Norway, } \\
\text { Netherlands, Belgium (Flanders)/ } \\
\text { Sweden, United States/ Ireland/ } \\
\text { Switzerland, and Italy }\end{array}$ \\
\hline
\end{tabular}


Chmielewski and Reardon (2016)

and Reardon (2016)
Progress in International Reading Literacy Study (PIRLS), Early

Childhood Longitudinal Study,

Kindergarten Class (ECLS-K)

Programme for International Student Assessment (PISA) 2006, ECLS-K
Association between parental

education and children's educational

attainment

Association between parental income and children's test scores

Association between parental income and children's test scores
United Kingdom, Greece, Sweden/

Denmark, Finland, Ireland,

Netherlands/ Slovakia/ Slovenia,

Germany/ Israel, Czech Republic,

Belgium, Norway, Hungary, Austria,

Italy, France, and Luxembourg

Iceland, Sweden, Norway,

Netherlands, Canada (Ontario),

England, Canada (Quebec), New

Zealand, Slovenia, Germany, Slovak

Republic, Greece, and United States

Iceland, Denmark, Poland, Korea,

New Zealand, Germany, United

States, Portugal, Luxembourg 
Table 2. Sample Sizes of the Models Estimating Sibling Correlations.

\begin{tabular}{|c|c|c|c|c|c|c|c|}
\hline Outcome & Finland & Germany & Norway & Sweden & $\begin{array}{l}\text { United } \\
\text { Kingdom }\end{array}$ & $\begin{array}{l}\text { United } \\
\text { States } \\
\text { (PSID) }\end{array}$ & $\begin{array}{l}\text { United } \\
\text { States (Add } \\
\text { Health) }\end{array}$ \\
\hline \multicolumn{8}{|c|}{ Panel A: Cognitive Skills } \\
\hline$N$ Individuals & & 2,006 & 284,110 & 652,940 & & 2,265 & 2,269 \\
\hline$N$ Families & & 1,441 & 230,896 & 536,224 & & 1,567 & 1,072 \\
\hline \multicolumn{8}{|c|}{ Panel B: School Grades } \\
\hline$N$ Individuals & & & 403,661 & $1,026,673$ & & & 1,620 \\
\hline$N$ Families & & & 271,162 & 683,546 & & & 1,040 \\
\hline \multicolumn{8}{|c|}{ Panel C: Final Educational Attainment } \\
\hline$N$ Individuals & 79,467 & 1,034 & 643,701 & $2,302,256$ & 5,017 & 5,578 & \\
\hline$N$ Families & 60,766 & 815 & 412,328 & $1,371,369$ & 4,131 & 2,866 & \\
\hline
\end{tabular}

Registers. United Kingdom: United Kingdom Household Longitudinal Study (Understanding Society), 8th Edition (DOI: 10.5255/UKDA-SN-

6614-9). United States: Panel Study of Income Dynamics (PSID); National Longitudinal Study of Adolescent to Adult Health (Add Health),

Carolina Population Center, University of North Carolina. 
Table 3. Overview over Respondent's Age and Birth Year by Outcome and Country.

\begin{tabular}{lcc}
\hline $\begin{array}{l}\text { Panel A: Cognitive Skills } \\
\text { Country }\end{array}$ & Age & Birth Year \\
\hline Germany & $16-17$ & $1987-1997$ \\
Norway & $17-20$ & $1967-1976$ \\
Sweden & $17-20$ & $1965-1977$ \\
United States (PSID) & $3-18$ & $1985-1997$ \\
United States (Add Health) & $11-18$ & $1976-1984$ \\
& & Birth Year \\
Panel B: School Grades & Age & $1985-1992$ \\
Country & 16 & $1982-1991$ \\
Norway & 16 & $1976-1980$ \\
Sweden & $14-18$ & \\
United States & & \\
& & \\
Panel C: Final Educational Attainment (Years of Education) & \\
Country & Age & $1974-1980$ \\
\hline Finland & 30 & $1976-1989$ \\
Germany & $25-38$ & $1970-1980$ \\
Norway & 30 & $1960-1982$ \\
Sweden & 30 & $1954-1989$ \\
United Kingdom & $25-43$ & $1954-1986$ \\
United States & $25-56$ & \\
\hline
\end{tabular}

Sources: Finland: Registers. Germany: Socio-Economic Panel Study (SOEP), v31.1 (DOI: 10.5684/soep.v31.1). Norway: Registers. Sweden:

Registers. United Kingdom: UK Household Longitudinal Study (Understanding Society), 8th Edition (DOI: 10.5255/UKDA-SN-6614-9). U.S.:

Panel Study of Income Dynamics (PSID); National Longitudinal Study of Adolescent to Adult Health (Add Health), Carolina Population Center,

University of North Carolina. 


\section{FIGURES}

Figure 1. Sibling Correlations in Cognitive Skills.

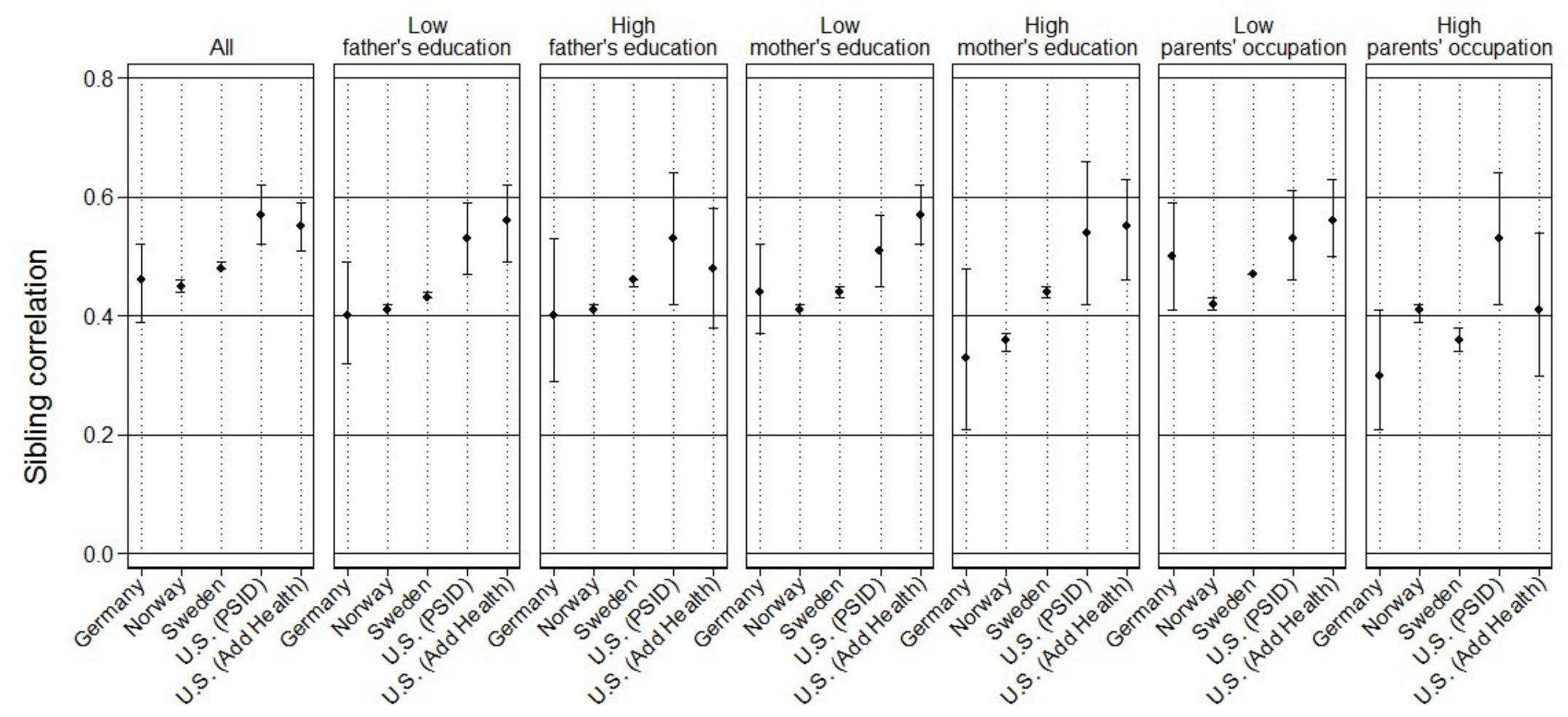

Note: $95 \%$ confidence intervals are bound to vary between 0 and 1 .

Sources: Germany: Socio-Economic Panel Study (SOEP), v31.1 (DOI: 10.5684/soep.v31.1). Norway: Registers. Sweden: Registers. United States: Panel Study of Income Dynamics (PSID); National Longitudinal Study of Adolescent to Adult Health (Add Health), Carolina Population Center, University of North Carolina. 
Figure 2. Sibling Correlations in School Grades.

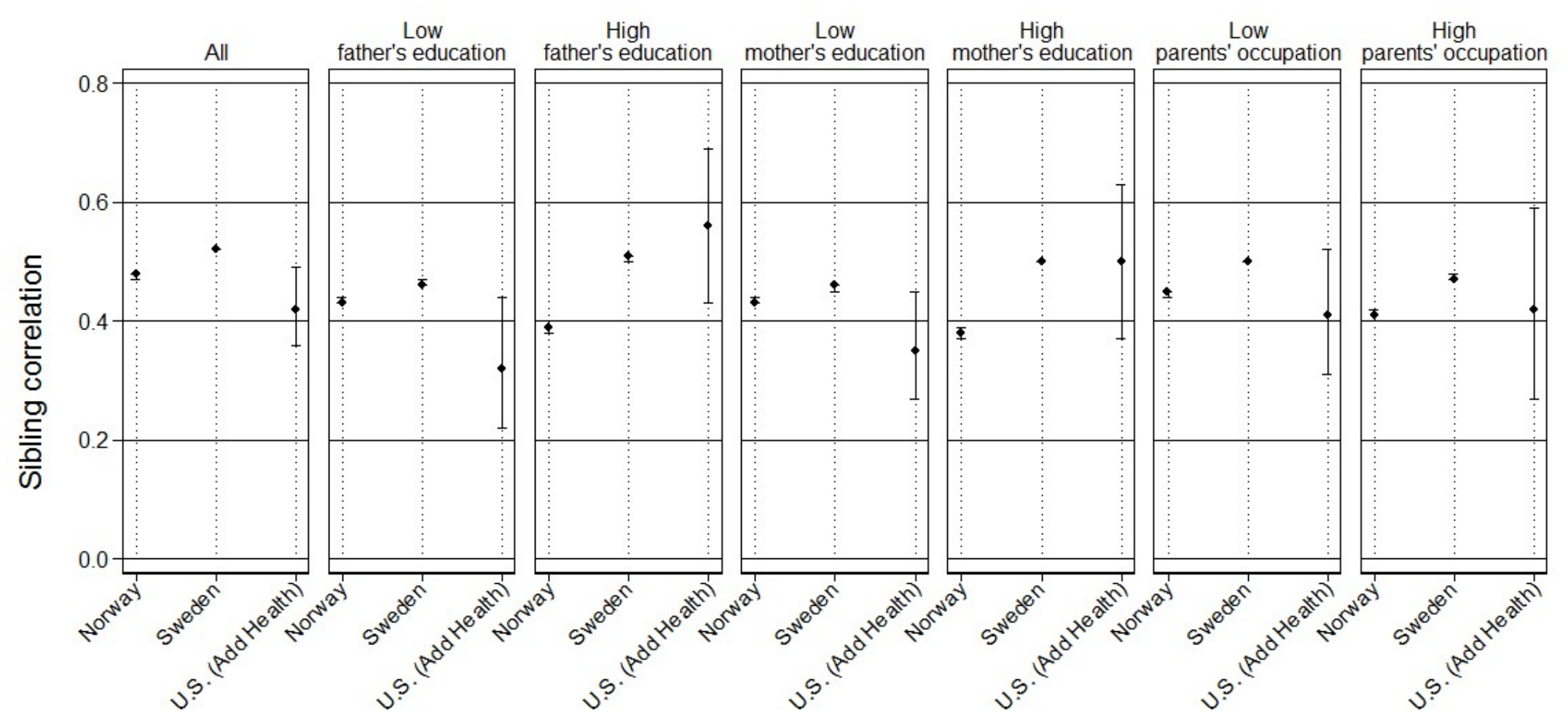

Note: $95 \%$ confidence intervals are bound to vary between 0 and 1 .

Sources: Norway: Registers. Sweden: Registers. United States: National Longitudinal Study of Adolescent to Adult Health (Add Health), Carolina Population Center, University of North Carolina. 
Figure 3. Sibling Correlations in Final Educational Attainment.

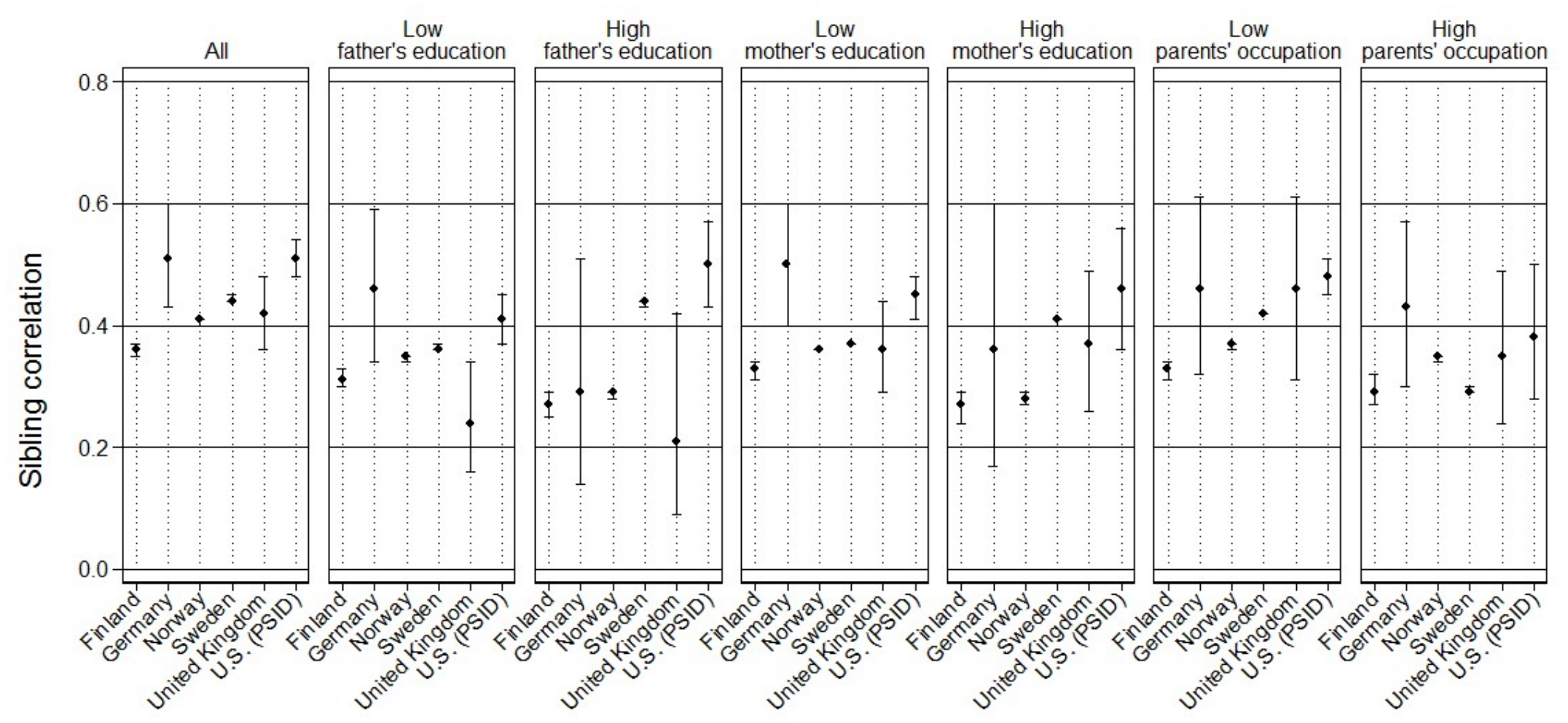

Note: $95 \%$ confidence intervals are bound to vary between 0 and 1 .

Sources: Finland: Registers. Germany: Socio-Economic Panel Study (SOEP), v31.1 (DOI: 10.5684/soep.v31.1). Norway: Registers. Sweden: Registers.

United Kingdom: UK Household Longitudinal Study (Understanding Society), 8th Edition (DOI: 10.5255/UKDA-SN-6614-9). United States: Panel Study of Income Dynamics (PSID). 


\section{Online Supplement to}

Universal Family Background Effects on Education Across and Within

Societies

This online supplement includes:

Appendix A. Details on the Specific Data Sets

Appendix B. Tables S1 to S12 


\section{Appendix A. Details on the Specific Data Sets}

Finland. The Finnish data is based on administrative registers combined by Statistics Finland. The data is based on a ten percent sample of the population alive in 1980. The sample has first been expanded to include information on all children, children's children, or subsequent generations born by 1991. Each of these is matched with spouses (cohabiting or married) by 2010 as well as linked with the biological parents of the spouse. For the analyses conducted here we included the sample persons and their children to ensure representativeness at the population level. The sample included approximately 15 percent of the birth cohort born between 1974 and 1980.

Outcome variable in the Finnish case is the educational degree people have achieved by age 30, measured in years of education. The information for this variable is observed between 2004 and 2010, depending on each annual birth cohort.

Background variables include father's and mother's education, parental occupation, and the number of siblings. Parental education was measured when the children were 15 years old, separately for both parents. Low education means basic or vocational upper secondary education (ammattikoulu) and high education refers to general upper secondary (ylioppilas), post-secondary non-higher education (opistokoulutus or similar), bachelor-level higher education, or higher education in either polytechnics or universities (ammattikorkeakoulu or yliopisto).

Parental EGP class was used to measure a high or a low level of parental occupation. A high level of parental occupation includes higher and lower service occupations (EGP class I and II) and self-employed with employees (IVa). A low level of parental occupation includes all other occupational categories. Parental occupation was measured around age 20 of all children. More precisely, it was measured in 1995 for cohorts born between 1974 and 1977 
(age 18 to 21) and in 2000 for cohorts born between 1978 and 1980 (age 20 to 22). This was due to occupations were only measured every five years during this period.

Number of siblings refers to all biological siblings from the mother's side. Siblings born after 1990 were not included. This results in minor underestimations of the number of siblings in the family although most siblings are born within short intervals.

Germany. For Germany, data from version 31.1 (DOI: 10.5684/soep.v31.1) of the German Socio-Economic Panel Study (SOEP) is used. There are two different samples constructed, one to analyze sibling similarity in cognitive skills and the other to estimate sibling correlations in educational attainment.

Cognitive skills are measured based on a test measuring cognitive potential conducted as part of the survey when respondents were age 16 to 17 . Educational attainment is a variable reporting the years of education needed to obtain a certain degree.

Parental background variables are based on parental education and occupation. Occupational information refers to the EGP class schema. A high level of maternal or paternal occupation is an occupation in EGP class I and II (professional and managerial occupations) or IVa (employers with employees), a low level all other occupations. A high level of maternal or paternal education is assigned if the mother or father holds the highest school-leaving certificate (Abitur) or an equivalent qualification, a low level for all qualifications below Abitur level. In addition to separate results for maternal and paternal occupation and education, we also report results for parental occupation and education. These models use the highest occupation or level of education obtained by one of the parents.

Norway. The Norwegian data comes from several different administrative registers, such as censuses, employer-employee registers, and the Norwegian educational data bases (NUDB). 
Individual-level anonymized data files are delivered by Statistics Norway. The Norwegian results are obtained using two distinct extracts from the register system. The first set of data, covers all Norwegians born after 1954. It is used to analyze the highest educational attainment among 30 year olds born between 1970 and 1980; and school grades for 16 year olds in the period 2001-2008. This second data set is used to analyze cognitive outcomes and covers the Norwegian birth cohorts 1967-1976.

Each outcome is analyzed on a specific sample. Our measure for cognitive ability comes from the Norwegian military conscription register. It is only available for men, and our sample is further limited to the members of the 1967-1976 Norwegian birth cohorts. Over $98 \%$ of conscripted individuals took the conscription test between the ages of 17 and 20, and so we exclude individuals who took the tests outside of these ages to keep the sample age homogenous. The cognitive ability test consists of several subtests that measured logical, spatial, verbal, and technical abilities. Each of these sub-tests is first evaluated on a normalized 9-point (stanine) scale. The subtest scores are summed to obtain an overall score and transformed onto a stanine scale with a mean of 5 and a standard deviation of 2 . The cognitive test includes three subtests of arithmetic, word similarities, and figures. A general cognitive ability score is the combined measure of the performance on the three tests seen together, obtained by transforming the raw scores in a standardization sample into normally distributed $\mathrm{F}$ scores $(\mathrm{M}=50, \mathrm{SD}=20)$. The $\mathrm{F}$ scores are added and subsequently transformed into stanine scores (with a mean of 5 and a standard deviation of 2).

Our two next dependent measures are not restricted by gender. Our measure of school grades is the sum of grade scores from compulsory-level school at the age of 16 . These scores are standardized. Information on these scores is available in the period 2001-2008. Consequently, the analyses of this outcome are restricted to those who received a grade at compulsory school level in the given time period; individuals born between 1985 and 1992 . 
Educational attainment is measured as the number of years of education that correspond to a specific educational level achieved by the age of 30 . In the analyses of educational attainment, we use birth cohorts born between 1970 and 1980 .

All individuals have information on demographic and family background variables. The following variables are used to obtain estimates of sibling similarity within subsamples: number of siblings, immigrant background, father and mother's education when the individuals were age 16, the mother and father's occupation. High parental education is defined if one of the parents obtained a university degree. High parental occupation is based on if one of the parents is a professional or manager. There are small differences in measurement between the two data sets. Parental occupation is measured in register data covering 2003-2008 in the first data set, while it is taken from the 1980 Census in the second data set (which cover an older population). The analysis of cognitive skills includes no migrants in the sample.

Sweden. In Sweden each individual has a unique personal identification number (PIN). This PIN makes it possible to link the records of an individual across the various administrative registers. This study draws heavily upon the Swedish multi-generational register. The multigenerational register contains information on the PIN of each individual and of that individual's parents. This allows us to identify the biological mother and father of each individual, and, in turn, to identify any other biological kin relations. The main family members of interest in this study are the mother, father, and siblings. We use information on the biological mother and father to identify the sibling group.

The data on GPA is taken from grades from the final year of grundskolan (Årkurs 9), which is the ninth year of compulsory education. Students are typically 16 years old in ninth grade. The system for assigning grades in the Swedish high school system has changed several times over the past decades, and so we limit our analyses to a period, 1998 to 2007, where the 
grade system stayed constant. This means studying cohorts born 1982 to 1991 , who were aged 16 between 1998 and 2007. During this period in the Swedish compulsory school system, grades could range from pass with special distinction, to pass with distinction, pass, or fail. To construct an overall score, each of these grades was assigned a numerical score, where pass with special distinction was equal to 20 , pass with distinction equal to 15 , pass equal to 10 , and fail equal to 0 . The overall GPA was calculated by summing the values for the 16 best grades achieved by any given pupil, and the overall range was therefore 0 to $320 .^{1}$

To examine educational attainment we use data on cohorts born 1960 to 1982, and look at the number of years of educational attainment achieved by age 30 . This measure is based upon the number of years of education that correspond to the specific level of education achieved by age 30, and may not in all cases reflect the actual number of years that an individual spent in the educational system.

Our measure for cognitive ability comes from the Swedish military conscription register but is only available for men as women were not required to take conscription tests in Sweden. Nevertheless, in our analyses of cognitive ability the measure of family size is based upon the full sibling group, including male and female siblings. In these analyses we use men born between 1965 and 1977. Over 98\% of conscripted individuals took the conscription test between the ages of 17 and 20. We exclude individuals who took the tests outside of these ages to keep the sample age homogenous. The cognitive ability test consisted of subtests that measured logical, spatial, verbal, and technical abilities. Each of these sub-tests was first evaluated on a normalized 9-point (stanine) scale. The subtest scores were summed to obtain an overall score and transformed onto a stanine scale with a mean of 5 and a standard deviation of 2 .

\footnotetext{
${ }^{1}$ Skolverket. 2010. "Facts and Figures about Pre-school Activities, School-age Childcare, Schools and Adult Education in Sweden 2010”. Stockholm: Swedish National Agency for Education.
} 
United Kingdom. For the United Kingdom, we use data from the 8th edition of "Understanding Society" (DOI: 10.5255/UKDA-SN-6614-9), the United Kingdom Household Longitudinal Study (UKHLS). Siblings refer to children born to the same mother.

Years of education are obtained as the answer to the questions how old respondents were you when they left school, or, if applicable, further education.

Parental education is based on the ISCED classification of parents' self-reported educational degrees with "low" education denoting degrees in the ISCED categories 0-4 and "high" in the categories 5 and 6. Parental occupation is based on the National Statistics Socioeconomic Classification (NS-SEC), with the "low" category comprising intermediate or routine and manual occupations and the "high" category managerial and professional occupations. Occupations were classified based on parents' self-reported occupations. If parents reported different occupations or educational degrees in different survey waves, we used the highest one reported. Migrant background refers to the situation that one or both of the parents were not born in the UK.

United States. For calculating sibling correlations in educational attainment for the U.S., we used the main dataset of the Panel Study of Income Dynamics (PSID). The PSID is a longitudinal, statistically representative survey which was collected annually from 1968 to 1997 and biennially thereafter up to the present. Because we wish to capture educational attainment during adulthood while also linking to parents' attributes in the main dataset, we focus on individuals who were either "heads" (in practice, usually the husband or adult male "breadwinner" of the household) or "wives" (in practice, usually adult women who married into or otherwise formed their own households) who were 25 years or older in any wave from 1983 to 2011. We iteratively obtained the earliest possible measures for education for the 
eligible heads and wives and their parents. We use 1968 as a baseline for obtaining information on parental education. The cut-off point for "high" and "low" levels of education was more than 15 years of attainment (corresponding to a bachelor's degree in the U.S.) and less than 16 years (high school graduate). With respect to final educational attainment, we do not stratify results based on father's and mother's occupational status because of the older cohorts included in our educational attainment data were largely dominated by single-earner households. For the PSID results stratified by occupational status, we offer estimates based on the occupation of the head of household (and 'wife' when stratifying in the newer modules), which in practice signifies the father (and mother) in the great majority of cases. (Occupational status is only available at the family unit level, so unlike education we cannot link individual data on children to their mothers and fathers, but only to the 'heads/wives' of their households.)

For measuring cognitive skills, we partly rely on the Child Development Supplement (CDS) of the PSID, which consists of children who were 0-12 at the first wave in 1997. Information was subsequently collected from children and their families in 2002 and 2007, unless they transitioned into adulthood (in that case becoming part of a more limited supplement, the Transition to Adulthood [TA] module). For our purposes, because children younger than three years old were not tested, our sample consists of children who were approximately $3-12$ in $1997,5-18$ in 2002 , and 10-18 in 2007 . Our measures of interest are an age-standardized overall score averaging percentile scores in applied problems (math) and broad reading (verbal). We averaged the cognitive scores over waves for children with multiple observations (i.e. a 4-year-old in 1997 who was retested at ages 9 and 14 in 2002 and 2007 waves, respectively). Our cognitive measures from the CDS consist specifically of WoodcockJohnson tests of cognitive abilities. The scores (already age-standardized) are then standardized to the sample of children, such that estimates are obtained for intra-family z-score correlations. Restricting the sample to older ages, which are more closely resembling the age restrictions in 
the other countries, results in sibling correlations at the population level of .52 (95\% CI: .47, .57 ; age $14-18 ; N=1,183)$ and $.48(95 \%$ CI: .38, 58; age $16-18 ; N=585)$. Hence, the estimates of the smaller age groups are smaller but not statistically significantly different to those obtained using ages 3-18. Therefore, these estimates would lead to even smaller variation across countries. Nevertheless we decided to use the larger age group in order to have larger sample sizes for the comparisons by family socioeconomic background.

We also used Add Health Picture Vocabulary Test (AHPVT) scores for measuring cognition, which is an abridged, age-standardized version of the Peabody Picture Vocabulary Test. Add Health (or the National Longitudinal Study of Adolescent to Adult Health) is a longitudinal study of adolescents which has started in 1994-1995 and includes follow-up waves in 1996, 2001-2002, 2008, and a planned fifth wave in 2016-2018. Our sample consists of Wave I respondents, who were enrolled in 7 th to 12 th grade in the $1994 / 1995$ school year. Because unique family identifiers (which are necessary for obtaining intra-family correlations) are only available on restricted contract, we use protected data to connect siblings to one another. Again, we tested how restricting the age at which cognitive scores are observed affected the estimates: we obtained sibling correlations at the population level of .55 (95\% CI: $.51,58$; age $14-18 ; N=1,537)$ and $.53(95 \%$ CI: .46, .60; age 16-18; $N=838)$. These estimates are again lower but not statistically significantly different for those obtained using ages 11-18.

For Grade Point Average (GPA), we again use Add Health data, but restrict our sample to 14 to 18 year olds in an effort to standardize grades by confining them to the years of secondary education in the United States, rather than, for example, comparing middle schoolers to their older siblings. GPA is measured on a conventional four-point scale rendered from the Wave I dataset, and, then, standardized to the sample by obtaining z-scores. Restricting the sample to those for which we observe grades at ages 16-18 $(N=944)$ leads to an estimated 
sibling similarity at the population level of $.41(95 \%$ CI: $.33, .49)$. This estimate is nearly identical to the estimate using ages $14-18$. 


\section{Appendix B. Tables S1 to S12}

Tables S1-3. Sibling Similarity in Cognitive Skills, School Grades, and Educational Attainment, Full Tables of Results

Table S1. Sibling Correlations in Cognitive Skills

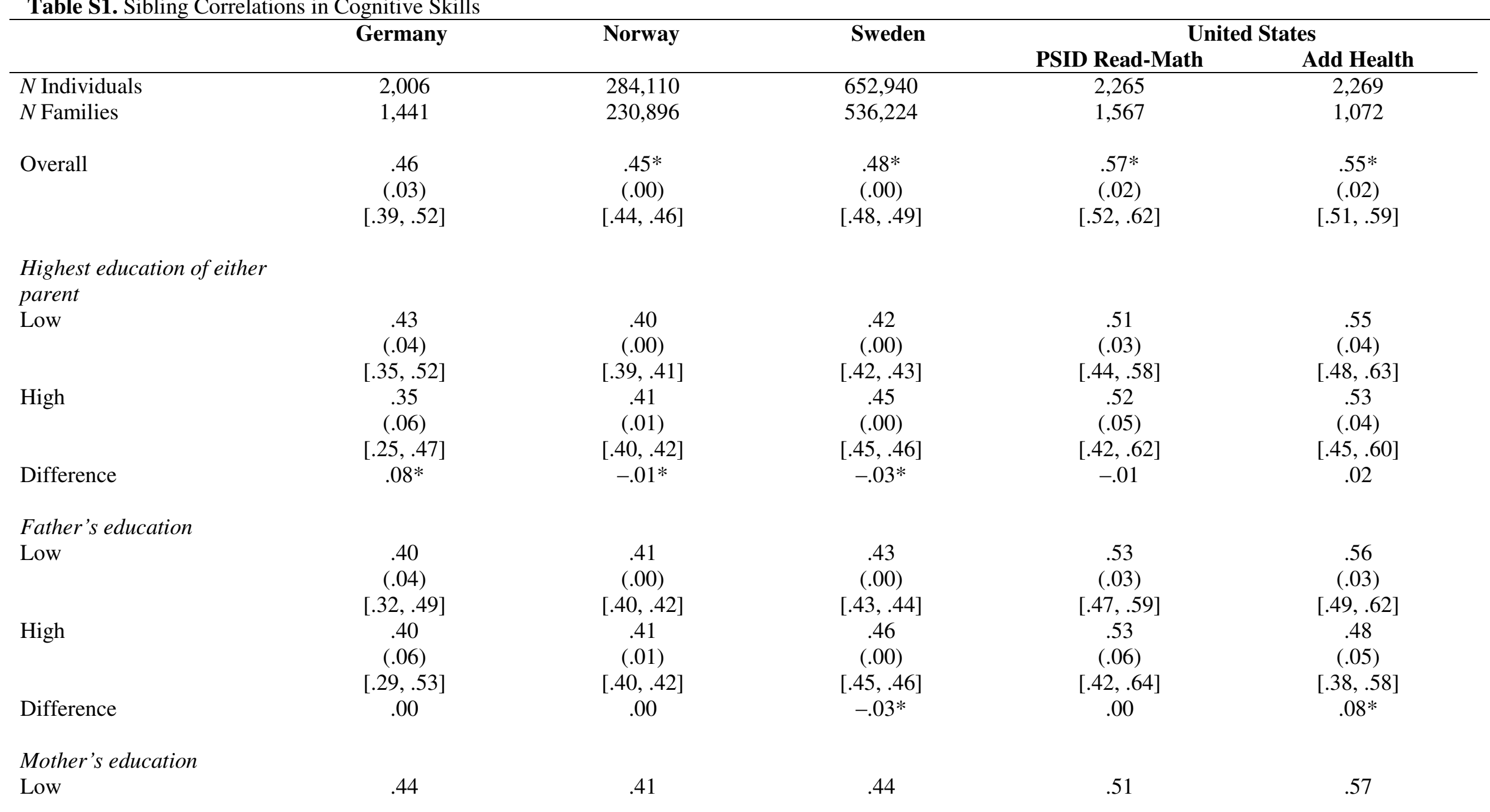




\begin{tabular}{|c|c|c|c|c|c|}
\hline & $(.04)$ & $(.00)$ & $(.00)$ & $(.03)$ & $(.03)$ \\
\hline & {$[.37, .52]$} & {$[.40, .42]$} & {$[.43, .45]$} & {$[.45, .57]$} & {$[.52, .62]$} \\
\hline \multirow[t]{3}{*}{ High } & .33 & .36 & .44 & .54 & .55 \\
\hline & $(.07)$ & $(.01)$ & $(.00)$ & $(.06)$ & $(.05)$ \\
\hline & {$[.21, .48]$} & {$[.34, .37]$} & {$[.43, .45]$} & {$[.42, .66]$} & {$[.46, .63]$} \\
\hline Difference & $.11 *$ & $.05^{*}$ & .00 & -.03 & .02 \\
\hline \multicolumn{6}{|c|}{$\begin{array}{l}\text { Highest parental } \\
\text { occupation }\end{array}$} \\
\hline \multirow[t]{3}{*}{ Low } & .50 & .42 & .47 & .53 & .56 \\
\hline & $(.05)$ & $(.00)$ & $(.00)$ & $(.04)$ & $(.03)$ \\
\hline & {$[.41, .59]$} & {$[.41, .43]$} & {$[.47, .47]$} & {$[.46, .61]$} & {$[.50, .63]$} \\
\hline \multirow[t]{3}{*}{ High } & .30 & .41 & .36 & .53 & .41 \\
\hline & $(.05)$ & $(.01)$ & $(.01)$ & $(.06)$ & $(.06)$ \\
\hline & {$[.21, .41]$} & {$[.39, .42]$} & {$[.34, .38]$} & {$[.42, .64]$} & {$[.30, .54]$} \\
\hline Difference & $.20 *$ & .01 & $.11 *$ & .00 & $.15^{*}$ \\
\hline \multicolumn{6}{|c|}{ Father's occupation } \\
\hline \multirow[t]{3}{*}{ Low } & .49 & .43 & .47 & .55 & .51 \\
\hline & $(.05)$ & $(.00)$ & $(.00)$ & $(.03)$ & $(.03)$ \\
\hline & {$[.41, .58]$} & {$[.42, .43]$} & {$[.47, .48]$} & {$[.49, .60]$} & {$[.46, .57]$} \\
\hline \multirow[t]{3}{*}{ High } & .29 & .41 & .35 & .56 & .38 \\
\hline & $(.06)$ & $(.01)$ & $(.01)$ & $(.07)$ & $(.07)$ \\
\hline & {$[.20, .41]$} & {$[.40, .42]$} & {$[.33, .37]$} & {$[.42, .69]$} & {$[.24, .53]$} \\
\hline Difference & $.20 *$ & $.02 *$ & $.12 *$ & -.01 & $.13^{*}$ \\
\hline \multicolumn{6}{|c|}{ Mother's occupation } \\
\hline \multirow[t]{3}{*}{ Low } & .46 & .44 & .47 & .56 & .57 \\
\hline & $(.05)$ & $(.00)$ & $(.00)$ & $(.03)$ & $(.02)$ \\
\hline & {$[.36, .55]$} & {$[.43, .44]$} & {$[.47, .48]$} & {$[.50, .62]$} & {$[.52, .62]$} \\
\hline \multirow[t]{3}{*}{ High } & .32 & .39 & .37 & .46 & .55 \\
\hline & $(.06)$ & $(.01)$ & $(.02)$ & $(.07)$ & $(.08)$ \\
\hline & {$[.22, .44]$} & {$[.37, .41]$} & {$[.35, .40]$} & {$[.34, .59]$} & {$[.38, .70]$} \\
\hline Difference & $.24 *$ & $.05^{*}$ & $.10 *$ & $.10 *$ & .02 \\
\hline
\end{tabular}




\section{Migration Background}

No migrant background

Migrant background

Family Size

3 children and less

More than 3 children

Difference

Maternal Age at Birth

25 or younger

26 or older

$[33,51]$

$.13 *$

$$
.40
$$

$[.32, .48$

$$
\text { (.07) }
$$

$[.34, .60]$

.07

$$
.47
$$

$[.41, .54]$

.31

(.14)

[.11 .63]

.16

6 $\mathrm{n} / \mathrm{a}$

$\mathrm{n} / \mathrm{a}$

$\mathrm{n} / \mathrm{a}$

.44

(.00)

$[.43, .45]$

.47

(.01)

$[.46, .48]$

$-.03 *$
.47

(.00)

$[.47, .48]$

.52

(.01)

$[.51, .53]$

$-.05 *$

47

(.00)

$[.46, .47]$

.55

(.00)

$[.54, .55]$

$-.08 *$
.57

$[.43, .45]$

.47

(.01)

$[.46, .49]$

$-.03 *$
.46

$[.45, .47]$

.50

(.00)

$[.49, .50]$
(.03)

$[.52, .62]$

.58

(.07)

$[.43, .71]$

.01

$\mathrm{n} / \mathrm{a}$

$\mathrm{n} / \mathrm{a}$

$\mathrm{n} / \mathrm{a}$

$\mathrm{n} / \mathrm{a}$

$\mathrm{n} / \mathrm{a}$

$\mathrm{n} / \mathrm{a}$

.56

.46

$[.40, .53]$

.59

$[.50, .66]$

$-.13 *$

$[.49, .65] \quad[.50, .62]$

$\begin{array}{ll}.54 & .54\end{array}$

$(.04) \quad(.04)$

$[.47, .61] \quad[.46, .62]$

03

Note: Standard errors in parentheses and $95 \%$ confidence intervals in square brackets.

* indicates (a) if attached to the population-level estimate: that the sibling correlation in a country is statistically significantly different from the weighted average sibling correlation of all other countries at the 5\% level; (b) if attached to the difference between social groups: that the conditional sibling

correlations at the group level are statistically significantly different from each other within the same country at the 5\% level. All differences are calculated using the unrounded sibling correlations.

Sources: Germany: Socio-Economic Panel Study (SOEP), v31.1 (DOI: 10.5684/soep.v31.1). Norway: Registers. Sweden: Registers. United States: Panel Study of Income Dynamics (PSID) and National Longitudinal Study of Adolescent to Adult Health (Add Health), Carolina Population Center, University of

North Carolina. 
Table S2. Sibling Correlations in School Grades

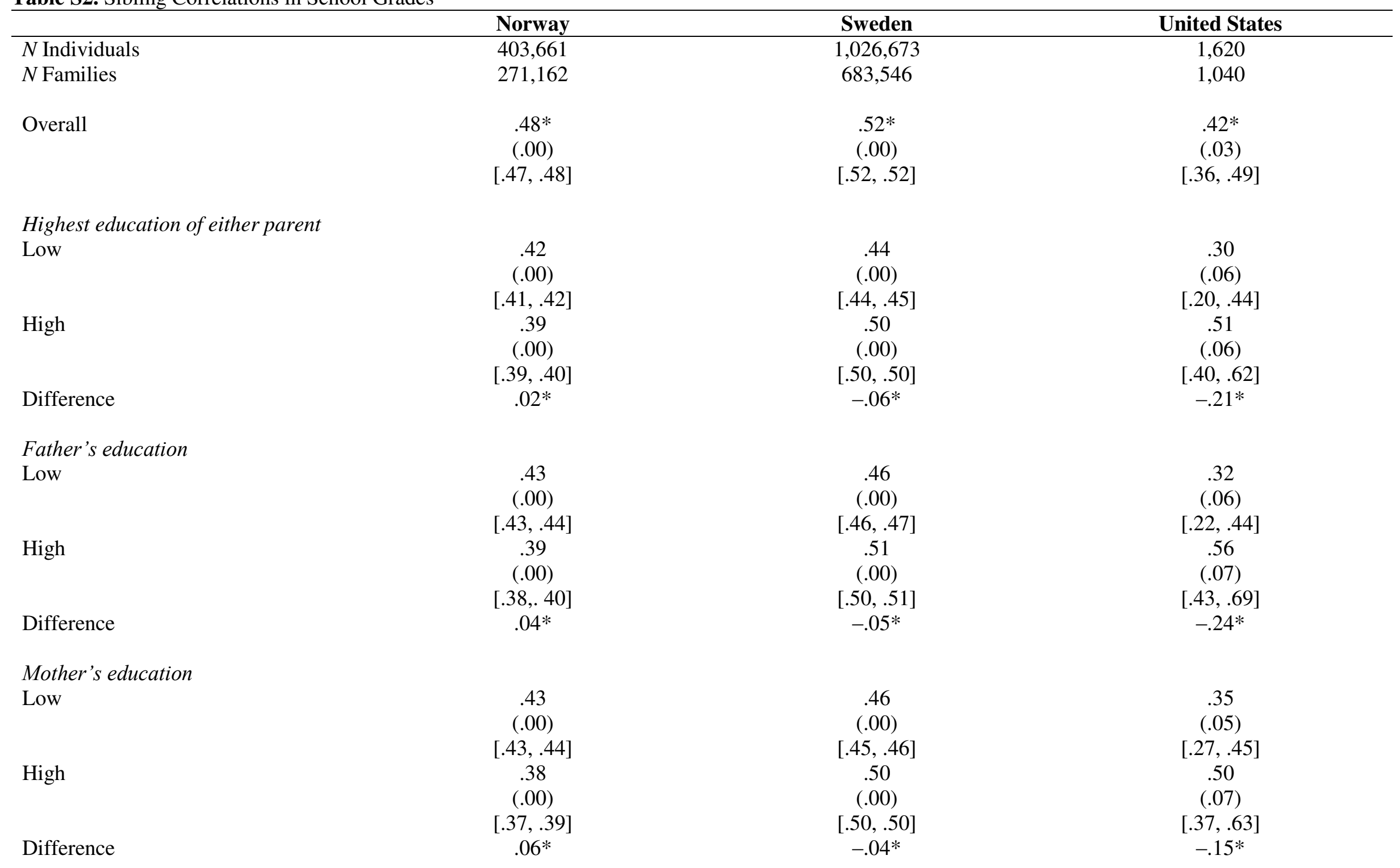


Highest parental occupation

High

\section{Difference}

Father's occupation

Low

High

.41

(.00)

$[.41, .42]$

$.04 *$

.51
$(.00)$
$[.50, .51]$
.48
$(.00)$
$[.47, .49]$
$.03 *$

$[.31, .52]$

.42

(.09)

$-.01$

\section{Difference}

$[.39, .41]$

$.05 *$

.51
$(.00)$
$[.51, .51]$
.48
$(.01)$
$[.47, .50]$
$03 *$

$(.04)$ $[.36, .52]$

.38

$[.16, .69]$

.06

Migration Background

No migrant background

.47
$(.00)$
$[.47, .48]$
.52
$(.01)$
$[.50, .54]$

.51
$(.00)$
$[.50, .52]$
.51
$(.00)$
$[.51, .52]$

(.05)

$[.33, .51]$

.49

(.07)

$[.36, .62]$ 


\section{Difference}

Family Size

3 children and less

More than 3 children

\section{Difference}

Maternal Age at Birth

25 or younger

26 or older

\section{Difference}

square brackets.

* indicates (a) if attached to the population-level estimate: that the sibling correlation in a country is statistically significantly different from the weighted average sibling correlation of all other countries at the $5 \%$ level; (b) if attached to the difference between social groups: that the conditional sibling correlations at the group level are statistically significantly different from each other within the same country at the 5\% level. All differences are calculated using the unrounded sibling correlations.

Sources: Norway: Registers. Sweden: Registers. United States: National Longitudinal Study of Adolescent to Adult Health (Add Health), Carolina Population Center, University of North Carolina. 
Table S3. Sibling Correlations in Final Educational Attainment (Years of Education)

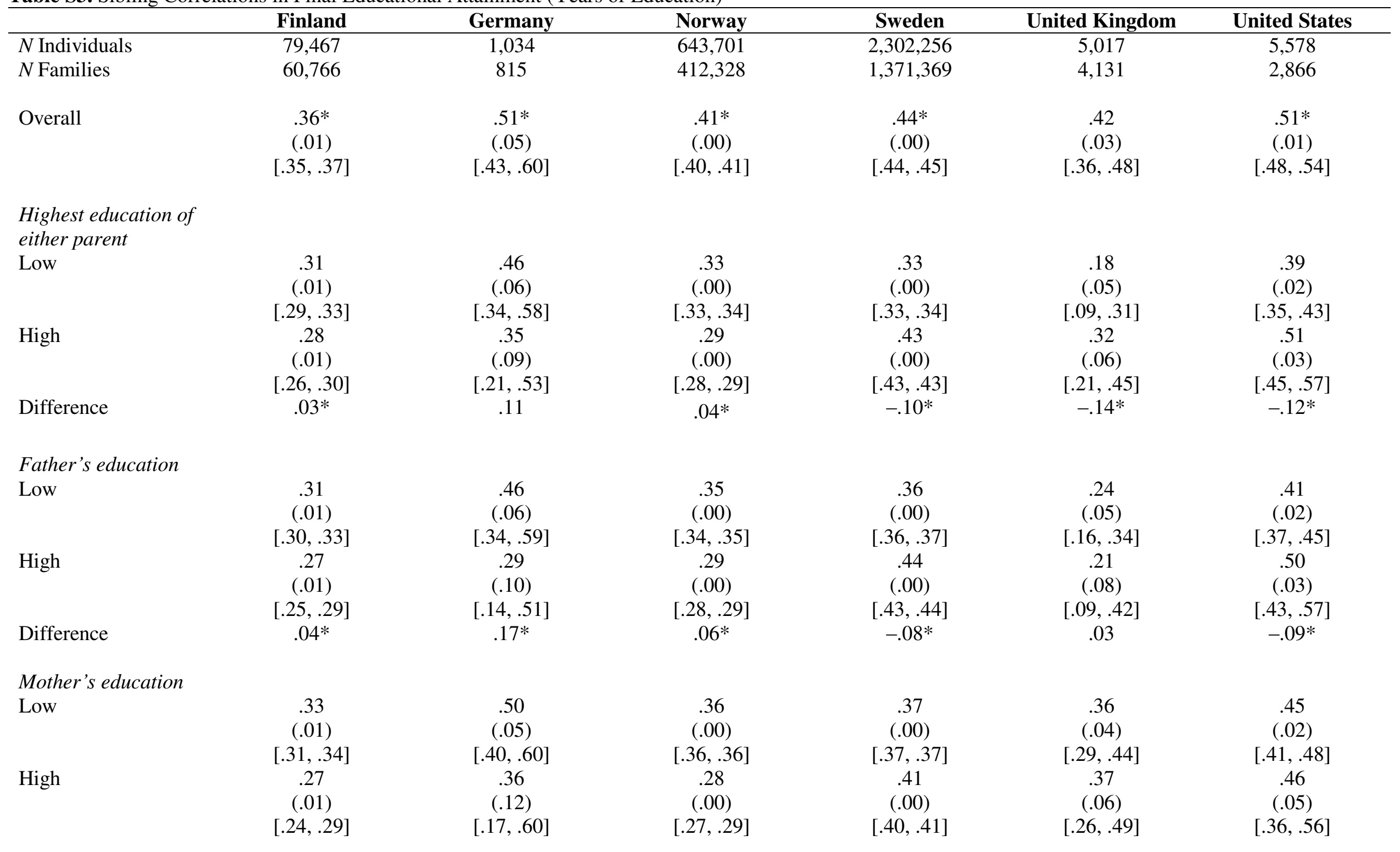




\begin{tabular}{|c|c|c|c|c|c|c|}
\hline Difference & $.06^{*}$ & $.14 *$ & $.08^{*}$ & $-.04 *$ & -.01 & -.01 \\
\hline \multicolumn{7}{|c|}{$\begin{array}{l}\text { Highest parental } \\
\text { occupation }\end{array}$} \\
\hline \multirow[t]{2}{*}{ Low } & $\begin{array}{c}.33 \\
(.01)\end{array}$ & $\begin{array}{c}.46 \\
(.08)\end{array}$ & $\begin{array}{c}.37 \\
(.00)\end{array}$ & $\begin{array}{c}.42 \\
(.00)\end{array}$ & $\begin{array}{c}.46 \\
(.08)\end{array}$ & $\begin{array}{l}.48 \\
(.02)\end{array}$ \\
\hline & {$[.31, .34]$} & {$[.32, .61]$} & {$[.36, .37]$} & {$[.42, .42]$} & {$[.31, .61]$} & {$[.45, .51]$} \\
\hline \multirow[t]{2}{*}{ High } & $\begin{array}{l}.29 \\
(.01)\end{array}$ & $\begin{array}{l}.43 \\
(.07)\end{array}$ & $\begin{array}{l}.35 \\
(.00)\end{array}$ & $\begin{array}{l}.29 \\
(.00)\end{array}$ & $\begin{array}{l}.35 \\
(.06)\end{array}$ & $\begin{array}{c}.38 \\
(.06)\end{array}$ \\
\hline & {$[.27, .32]$} & {$[.30, .57]$} & {$[.34, .35]$} & {$[.29, .30]$} & {$[.24, .49]$} & {$[.28, .50]$} \\
\hline Difference & $.03 *$ & .03 & $.02 *$ & $.13^{*}$ & $.11 *$ & $.10^{*}$ \\
\hline \multicolumn{7}{|c|}{ Father's occupation } \\
\hline Low & $\begin{array}{c}.32 \\
(.01) \\
{[.31 .34]}\end{array}$ & $\begin{array}{c}.42 \\
(.08) \\
{[.28, .57]}\end{array}$ & $\begin{array}{c}.37 \\
(.00) \\
{[.37 .387}\end{array}$ & $\begin{array}{c}.43 \\
(.00) \\
{[.43, .43]}\end{array}$ & $\begin{array}{c}.27 \\
(.05) \\
{[.18, .38]}\end{array}$ & $\mathrm{n} / \mathrm{a}$ \\
\hline High & $\begin{array}{c}.29 \\
(.01) \\
{[.27, .32]}\end{array}$ & $\begin{array}{c}.46 \\
(.07) \\
{[.32, .60]}\end{array}$ & $\begin{array}{c}.35 \\
(.00) \\
{[.34, .36]}\end{array}$ & $\begin{array}{c}.30 \\
(.00) \\
{[.29, .31]}\end{array}$ & $\begin{array}{c}.28 \\
(.07) \\
{[.16, .45]}\end{array}$ & $\mathrm{n} / \mathrm{a}$ \\
\hline Difference & $.03 *$ & -.04 & $.02 *$ & $.13^{*}$ & -.01 & $\mathrm{n} / \mathrm{a}$ \\
\hline \multicolumn{7}{|c|}{ Mother's occupation } \\
\hline Low & $\begin{array}{c}.34 \\
(.01) \\
{[.32, .35]}\end{array}$ & $\begin{array}{c}.60 \\
(.06) \\
{[.49, .71]}\end{array}$ & $\begin{array}{c}.38 \\
(.00) \\
{[.38, .38]}\end{array}$ & $\begin{array}{c}.44 \\
(.00) \\
{[.43, .44]}\end{array}$ & $\begin{array}{c}.42 \\
(.05) \\
{[.34, .51]}\end{array}$ & $\mathrm{n} / \mathrm{a}$ \\
\hline High & $\begin{array}{c}.30 \\
(.01) \\
{[.27, .33]}\end{array}$ & $\begin{array}{c}.35 \\
(.10) \\
{[.18, .57]}\end{array}$ & $\begin{array}{c}.33 \\
(.01) \\
{[.32, .34]}\end{array}$ & $\begin{array}{c}.26 \\
(.01) \\
{[.25, .27]}\end{array}$ & $\begin{array}{c}.32 \\
(.06) \\
{[.22, .45]}\end{array}$ & $\mathrm{n} / \mathrm{a}$ \\
\hline Difference & $.04 *$ & $.25^{*}$ & $.05^{*}$ & $.18^{*}$ & $.10^{*}$ & $\mathrm{n} / \mathrm{a}$ \\
\hline \multicolumn{7}{|l|}{ Migration } \\
\hline $\begin{array}{l}\text { No migrant } \\
\text { background }\end{array}$ & $\mathrm{n} / \mathrm{a}$ & $\begin{array}{l}.45 \\
(.05)\end{array}$ & $\begin{array}{l}.40 \\
(.00)\end{array}$ & $\begin{array}{c}.44 \\
(.00)\end{array}$ & $\begin{array}{l}.38 \\
(.06)\end{array}$ & $\mathrm{n} / \mathrm{a}$ \\
\hline
\end{tabular}




\begin{tabular}{|c|c|c|c|c|c|c|}
\hline \multirow{4}{*}{ Migrant background } & & {$[.35, .56]$} & {$[.40, .41]$} & {$[.44, .45]$} & {$[.28, .50]$} & \multirow{4}{*}{$\mathrm{n} / \mathrm{a}$} \\
\hline & $\mathrm{n} / \mathrm{a}$ & .70 & .43 & .43 & .23 & \\
\hline & & $(.07)$ & $(.01)$ & $(.00)$ & $(.06)$ & \\
\hline & & {$[.56, .82]$} & {$[.41, .45]$} & {$[.43, .44]$} & [.14 .36] & \\
\hline Difference & $\mathrm{n} / \mathrm{a}$ & $-.25 *$ & $-.02 *$ & $.01 *$ & $.15^{*}$ & $\mathrm{n} / \mathrm{a}$ \\
\hline \multicolumn{7}{|l|}{ Family Size } \\
\hline \multirow[t]{3}{*}{3 children and less } & .35 & .50 & .39 & .44 & .48 & .51 \\
\hline & $(.01)$ & $(.05)$ & $(.00)$ & $(.00)$ & $(.03)$ & $(.03)$ \\
\hline & {$[.34, .37]$} & {$[.41, .59]$} & {$[.38, .39]$} & {$[.43, .44]$} & {$[.42, .54]$} & {$[.47, .55]$} \\
\hline \multirow[t]{3}{*}{ More than 3 children } & .37 & .54 & .42 & .45 & .13 & .47 \\
\hline & $(.01)$ & $(.22)$ & $(.00)$ & $(.00)$ & $(.06)$ & $(.02)$ \\
\hline & {$[.35, .39]$} & {$[.17, .87]$} & {$[.41, .42]$} & {$[.45, .45]$} & {$[.05, .30]$} & {$[.42, .52]$} \\
\hline Difference & .02 & .04 & $.03 *$ & $.01 *$ & $-.35^{*}$ & .04 \\
\hline \multicolumn{7}{|l|}{$\begin{array}{l}\text { Maternal Age at } \\
\text { Birth }\end{array}$} \\
\hline \multirow[t]{4}{*}{25 or younger } & .34 & .43 & .39 & .42 & .45 & .47 \\
\hline & $(.01)$ & (.10) & $(.00)$ & $(.00)$ & $(.04)$ & $(.02)$ \\
\hline & {$[.32, .36]$} & {$[.24, .63]$} & {$[.38, .39]$} & {$[.41, .42]$} & {$[.37, .54]$} & {$[.43, .52]$} \\
\hline & .35 & .53 & .41 & .46 & .37 & .55 \\
\hline \multirow{2}{*}{26 or older } & $(.01)$ & $(.07)$ & $(.00)$ & $(.00)$ & $(.05)$ & $(.02)$ \\
\hline & {$[.34, .37]$} & {$[.40, .65]$} & {$[.40, .41]$} & {$[.46, .46]$} & {$[.28, .46]$} & {$[.51, .60]$} \\
\hline Difference & .01 & $.10 *$ & $.02 *$ & $.04 *$ & $-.08 *$ & $.08^{*}$ \\
\hline
\end{tabular}

Note: Standard errors in parentheses and $95 \%$ confidence intervals in square brackets.

* indicates (a) if attached to the population-level estimate: that the sibling correlation in a country is statistically significantly different from the weighted average sibling correlation of all other countries at the $5 \%$ level; (b) if attached to the difference between social groups: that the conditional sibling

correlations at the group level are statistically significantly different from each other within the same country at the 5\% level. All differences are calculated using the unrounded sibling correlations.

Sources: Finland: Registers. Germany: Socio-Economic Panel Study (SOEP), v31.1 (DOI: 10.5684/soep.v31.1). Norway: Registers. Sweden: Registers.

United Kingdom: UK Household Longitudinal Study (Understanding Society), 8th edition (DOI: 10.5255/UKDA-SN-6614-9). United States: Panel Study of Income Dynamics (PSID). 
Tables S4-6. Sibling Similarity in Cognitive Skills, School Grades, and Educational Attainment, Robustness Check Using Only Siblings

Table S4. Sibling Correlations in Cognitive Skills

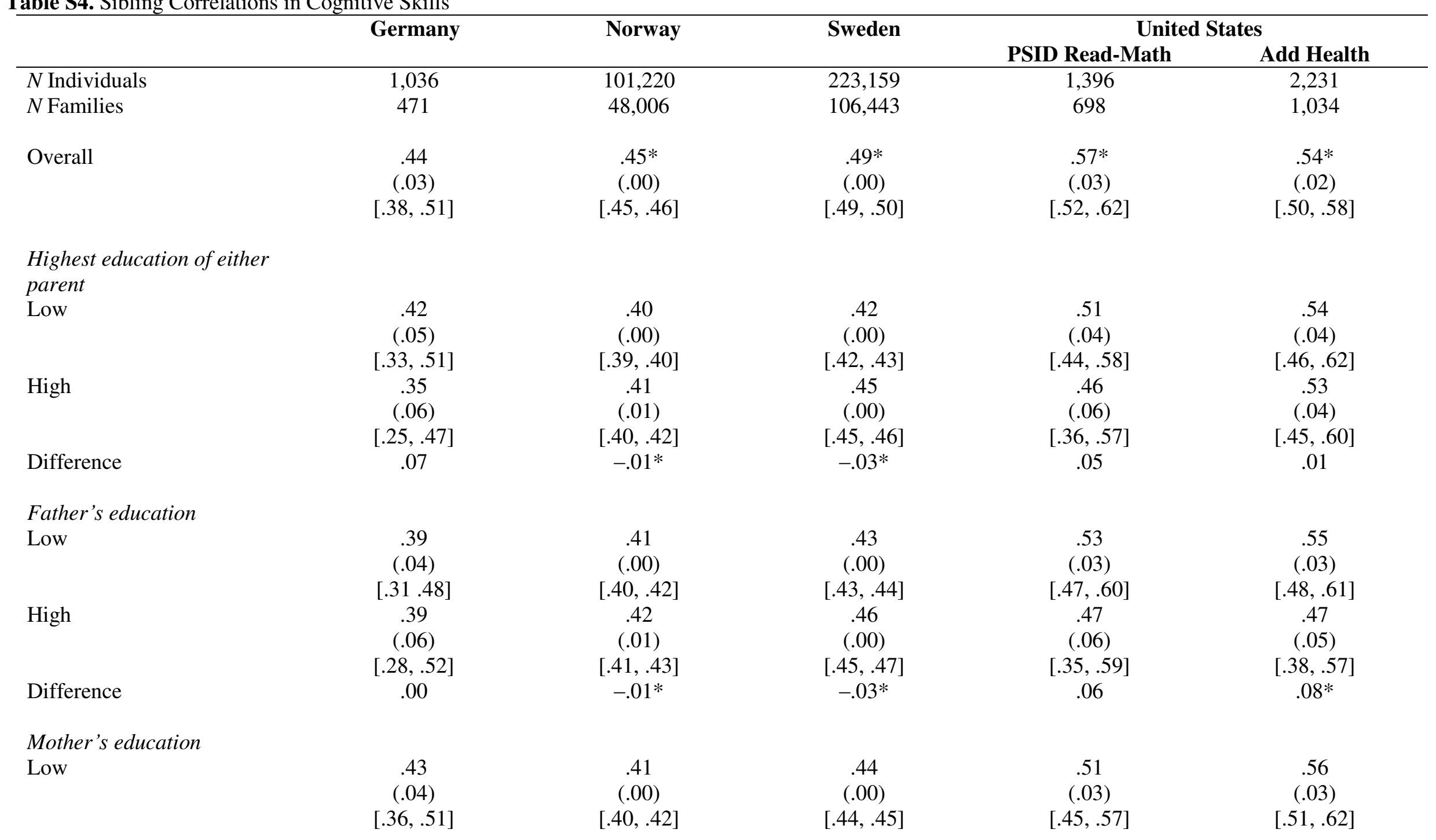


High

Difference

.32
$(.07)$
$[.20, .47]$

.11

$[.34, .37]$

Highest parental occupation

Low

High

Difference

Father's occupation

Low

High

Difference

Mother's occupation

Low

High

Difference

Migration background

No migrant background

.49
$(.05)$
$[.39, .58]$

.29

(.05)

$[.20, .41]$

$.20 *$

.48

(.05)

$[.39, .58]$

.29

(.06)

$[.19, .41]$

$.27 *$

.42
$(.00)$
$[.41, .43]$

$[.42, .43]$

$[.40, .43]$

.43

(.05)

$[.33, .53]$

.32
$(.06)$

$[.22, .44]$

$.11^{*}$

.38

(.04)

$[.31, .46]$
.35

$.06^{*}$

.41

(.00)

$[.40, .41]$

.01

.42

(.00)

.41

(.01)

.01

.44
$(.00)$
$[.43, .45]$

.00

.48

$[.47, .48]$

.36

(.01)

$[.34, .38]$

$.12 *$

.48

(.00)

$[.48, .48]$

.35

(.01)

$[.33, .37]$

$.13 *$

.44
$(.00)$
$[.43, .45]$
.39
$(.01)$
$[.37, .41]$
$.05^{*}$

$.05^{*}$

n/a

.48
$(.00)$
$[.48, .49]$
.37
$(.02)$
$[.34, .41]$
$.11^{*}$
.46
$(.07)$
$[.34, .59]$

.05

.54

$[.46, .61]$

.49

(.06)

$[.37, .60]$

.05

.55
$(.03)$

$[.49, .61]$

.47

(.08)

$[.33, .62]$

.08

.48

(.00)

$[.47, .48]$
.54

$[.45, .63]$

.02

.56

$[.50, .63]$

.41

(.06)

$[.30, .54]$

$.15^{*}$

.51

(.03)

$[.45, .57]$

.38

(.08)

$[.24, .53]$

$.13^{*}$

.57

(.02)

$[.52, .62]$

.55

(.08)

$[.38, .70]$

.02

.46

(.02)

$[.42, .51]$ 


\begin{tabular}{|c|c|c|c|c|c|}
\hline Migrant background & $\begin{array}{c}.44 \\
(.07) \\
{[.30, .58]} \\
-.06\end{array}$ & $\mathrm{n} / \mathrm{a}$ & $\begin{array}{c}.54 \\
(.01) \\
{[.52, .55]} \\
-.06^{*}\end{array}$ & $\begin{array}{c}.59 \\
(.08) \\
{[.43, .73]} \\
-.03\end{array}$ & $\begin{array}{c}.57 \\
(.04) \\
{[.49, .65]} \\
-.11\end{array}$ \\
\hline \multicolumn{6}{|l|}{ Family Size } \\
\hline 3 children and less & $\begin{array}{c}.46 \\
(.04) \\
{[.39, .53]}\end{array}$ & $\begin{array}{c}.44 \\
(.00) \\
{[.43, .45]}\end{array}$ & $\begin{array}{c}.47 \\
(.00) \\
{[.47, .48]}\end{array}$ & $\mathrm{n} / \mathrm{a}$ & $\mathrm{n} / \mathrm{a}$ \\
\hline More than 3 children & $\begin{array}{c}.25 \\
(.13) \\
{[.08, .56]}\end{array}$ & $\begin{array}{c}.47 \\
(.01) \\
{[.46, .49]}\end{array}$ & $\begin{array}{c}.56 \\
(.00) \\
{[.55, .56]}\end{array}$ & $\mathrm{n} / \mathrm{a}$ & $\mathrm{n} / \mathrm{a}$ \\
\hline Difference & $.21 *$ & $-.03 *$ & $.09 *$ & $\mathrm{n} / \mathrm{a}$ & $\mathrm{n} / \mathrm{a}$ \\
\hline \multicolumn{6}{|l|}{ Maternal Age at Birth } \\
\hline 25 or younger & $\begin{array}{c}.53 \\
(.06)\end{array}$ & $\begin{array}{c}.44 \\
(.01)\end{array}$ & $\begin{array}{c}.47 \\
(.00)\end{array}$ & $\begin{array}{c}.58 \\
(.04)\end{array}$ & $\begin{array}{c}.57 \\
(.03)\end{array}$ \\
\hline & {$[.41, .65]$} & {$[.43, .45]$} & {$[.46, .48]$} & {$[.49, .66]$} & {$[.50, .63]$} \\
\hline 26 or older & $\begin{array}{c}.41 \\
(.05)\end{array}$ & $\begin{array}{c}.48 \\
(.01)\end{array}$ & $\begin{array}{c}.51 \\
(.00)\end{array}$ & $\begin{array}{c}.52 \\
(.04)\end{array}$ & $\begin{array}{c}.54 \\
(.04)\end{array}$ \\
\hline & {$[.32, .50]$} & {$[.46, .49]$} & {$[.50, .51]$} & {$[.45, .60]$} & {$[.46, .62]$} \\
\hline Difference & $.12 *$ & $-.04 *$ & $-.04 *$ & .06 & .03 \\
\hline
\end{tabular}

Note: Standard errors in parentheses and $95 \%$ confidence intervals in square brackets.

* indicates (a) if attached to the population-level estimate: that the sibling correlation in a country is statistically significantly different from the weighted average sibling correlation of all other countries at the $5 \%$ level; (b) if attached to the difference between social groups: that the conditional sibling

correlations at the group level are statistically significantly different from each other within the same country at the 5\% level. All differences are calculated using the unrounded sibling correlations.

Sources: Germany: Socio-Economic Panel Study (SOEP), v31.1 (DOI: 10.5684/soep.v31.1). Norway: Registers. Sweden: Registers. United States: Panel Study of Income Dynamics (PSID) and National Longitudinal Study of Adolescent to Adult Health (Add Health), Carolina Population Center, University of North Carolina. 
Table S5. Sibling Correlations in School Grades

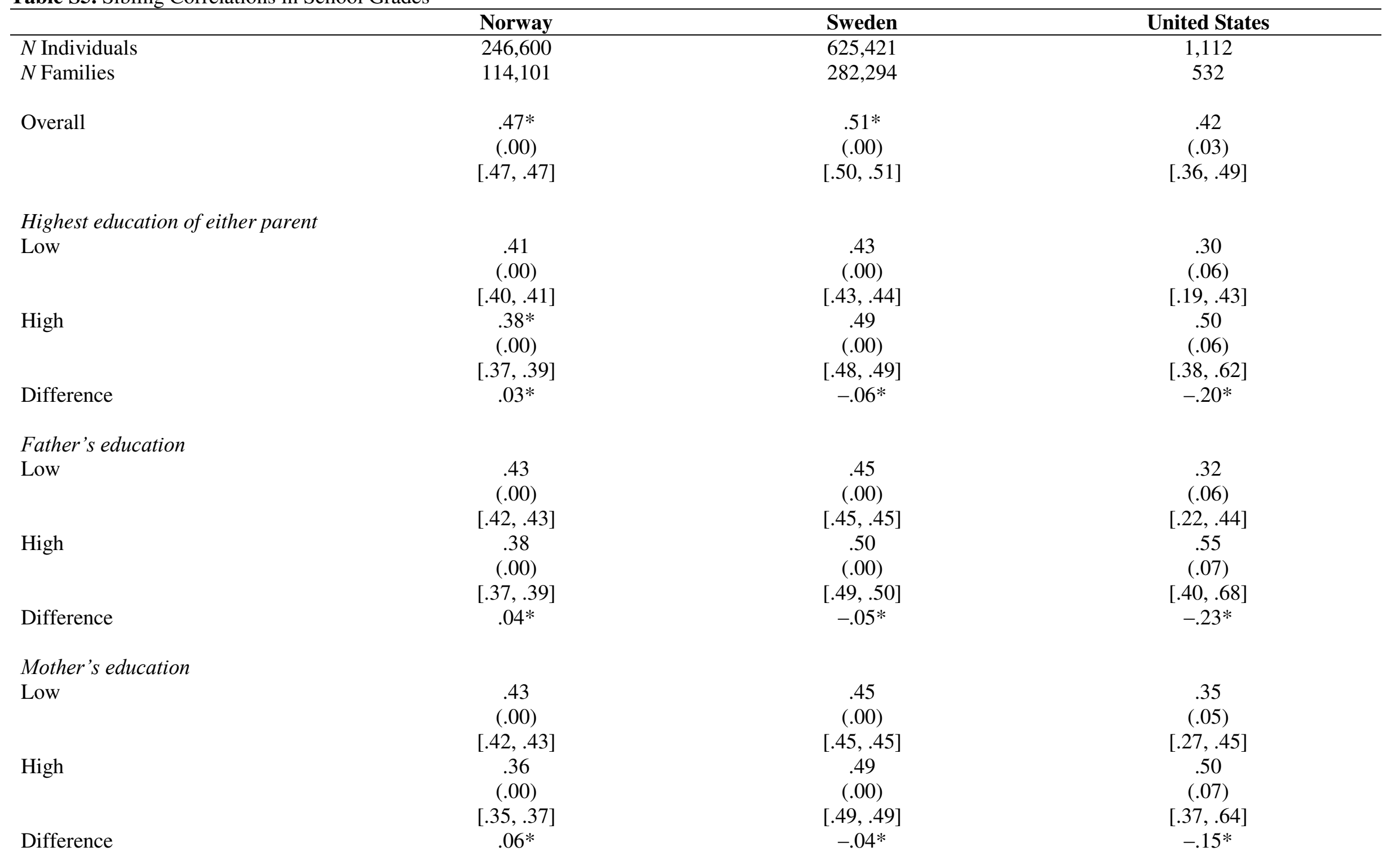


Highest parental occupation

High

\section{Difference}

\section{Father's occupation}

Low

High

Difference

\section{Mother's occupation}

Low

\section{High}

\section{Migration background}

No migrant background

Migrant background

.46
$(.00)$
$[.46, .47]$
.51
$(.01)$
$[.49, .53]$

.41
$(.05)$
$.32, .50]$
.49
$(.07)$
$.36, .63]$


Family size

3 children and less

.45

(.00)

$[.44, .45]$

More than 3 children

Difference

$[.49, .50]$

$-.05^{*}$

.43

(.00)

$[.42, .44]$

26 or older

(.00)

$[.45, .47]$

$-.03 *$
$[.52, .53]$

$-.03 *$

.46

(.00)

$[.45, .46]$

.52

(.00)

$[.51, .52]$

$-.06 *$ $\mathrm{n} / \mathrm{a}$

$\mathrm{n} / \mathrm{a}$

$\mathrm{n} / \mathrm{a}$

.44

$-.01$

Note: Standard errors in parentheses and $95 \%$ confidence intervals in square brackets.

* indicates (a) if attached to the population-level estimate: that the sibling correlation in a country is statistically significantly different from the weighted average sibling correlation of all other countries at the 5\% level; (b) if attached to the difference between social groups: that the conditional sibling correlations at the group level are statistically significantly different from each other within the same country at the 5\% level. All differences are calculated using the unrounded sibling correlations.

Sources: Norway: Registers. Sweden: Registers. United States: National Longitudinal Study of Adolescent to Adult Health (Add Health), Carolina Population Center, University of North Carolina. 
Table S6. Sibling Correlations in Final Educational Attainment (Years of Education)

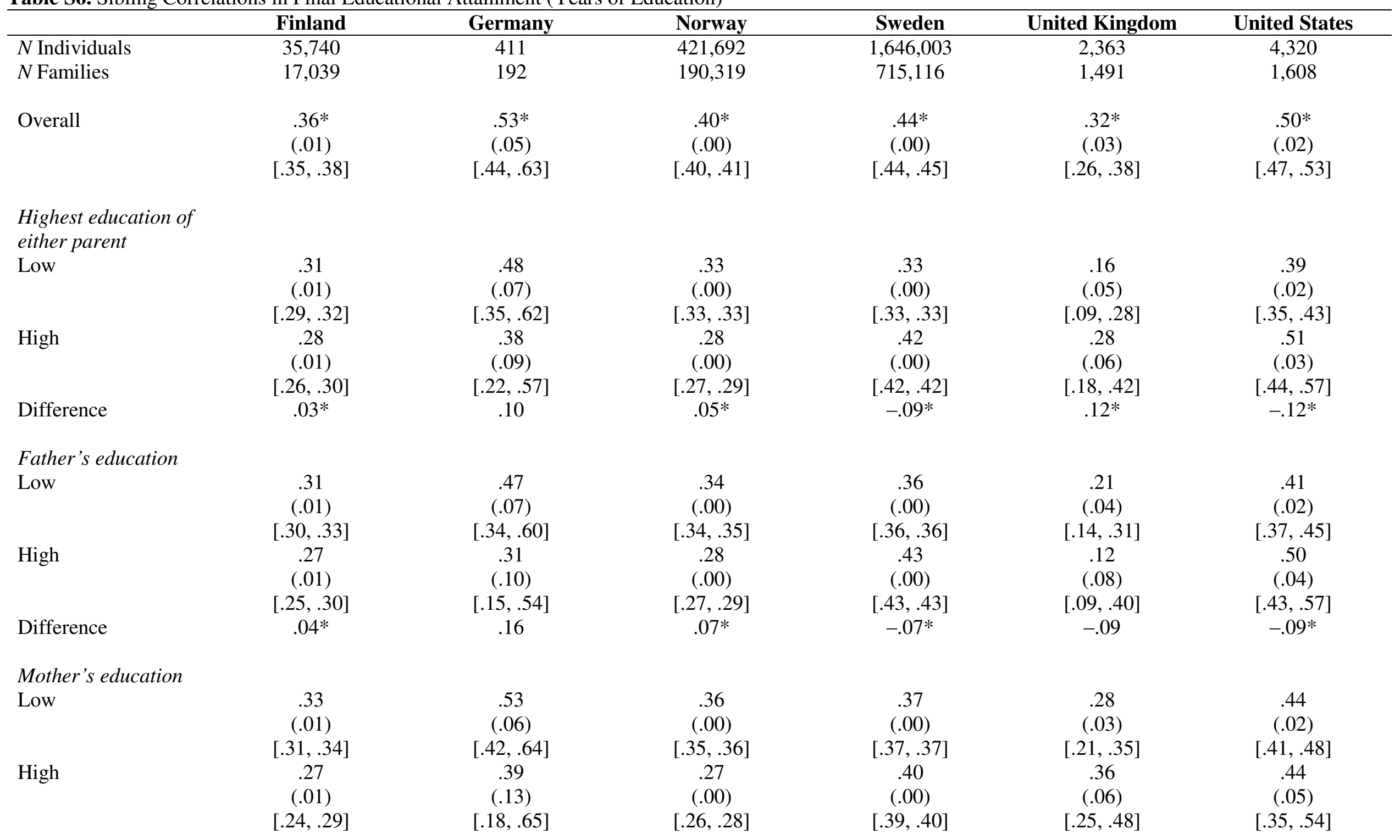


Difference

$.06 *$

.14

$.09 *$

$-.03 *$

.08

.00

Highest parental

occupation

Low

High

Difference

(.01)

.29

(.01)

$[.27, .32]$

Father's occupation

Low

.32

(.01)

$[.30, .34]$

High

Difference

$[.27, .32]$

Mother's occupation

Low

High

Difference

.34

(.01)

$[.32, .35]$

.29

$[.26, .33]$

$.04 *$

\section{Migration}

background

No migrant

background
$.03 *$

(.01)

$.03 *$

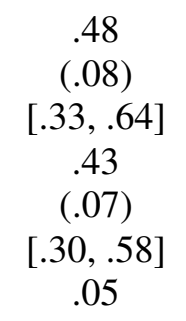

.44

$[.28, .61]$

.45

(.08)

$[.31, .60]$

$-.01$

.62

(.06)

$[.49, .73]$

.36

(.11)

$[.18, .58]$

$.26 *$

$\mathrm{n} / \mathrm{a}$

.47

$[.36, .58]$
.36

(.00)

.34

(.00)

$[.34, .35]$

$.02 *$

.37

(.00)

$[.36, .37]$

.35

(.00)

$[.34, .36]$

$.02 *$

.38

(.00)

.33

(.01)

$[.31, .34]$

$.05 *$

.40

$[.40, .41]$
.42

$[.42, .42]$

.29

(.01)

$[.28, .30]$

$.13 *$

.43

(.00)

$[.43, .43]$

.29

(.00)

$[.28, .30]$

$.14 *$

.44

(.00)

$[.43, .44]$

.25

(.01)

[.24, .27]

$.19 *$

.44

(.00)

$[.44, .45]$
.39
$(.08)$

$[.26, .55]$

.30

(.06)

$[.20, .43]$

$-.09$

.24

(.05)

$[.16, .35]$

.25

(.07)

$[.14, .41]$

$-.01$

.48

$[.44, .51]$

.37

(.06)

$[.27, .49]$

$.11 *$

$\mathrm{n} / \mathrm{a}$

n/a

n/a

$\mathrm{n} / \mathrm{a}$

(.06)

$[.27, .44]$

.29
$(.05)$

$[.19, .41]$

.06

$\mathrm{n} / \mathrm{a}$

$\mathrm{n} / \mathrm{a}$ 


\begin{tabular}{|c|c|c|c|c|c|c|}
\hline Migrant background & $\mathrm{n} / \mathrm{a}$ & $\begin{array}{c}.72 \\
(.08) \\
{[.54, .84]} \\
-.25^{*}\end{array}$ & $\begin{array}{c}.42 \\
(.01) \\
{[.39, .44]} \\
-.01 *\end{array}$ & $\begin{array}{c}.43 \\
(.00) \\
{[.43, .44]} \\
.01^{*}\end{array}$ & $\begin{array}{c}.22 \\
(.03) \\
{[.13, .35]} \\
.08\end{array}$ & $\mathrm{n} / \mathrm{a}$ \\
\hline \multicolumn{7}{|l|}{ Family size } \\
\hline 3 children and less & $\begin{array}{c}.36 \\
(.01) \\
{[.34, .37]}\end{array}$ & $\begin{array}{c}.52 \\
(.05) \\
{[.42, .62]}\end{array}$ & $\begin{array}{c}.39 \\
(.00) \\
{[.38, .39]}\end{array}$ & $\begin{array}{c}.43 \\
(.00) \\
{[.43, .44]}\end{array}$ & $\begin{array}{c}.37 \\
(.03) \\
{[.31, .43]}\end{array}$ & $\begin{array}{c}.50 \\
(.02) \\
{[.47, .54]}\end{array}$ \\
\hline More than 3 children & $\begin{array}{c}.37 \\
(.01) \\
{[.34, .39]}\end{array}$ & $\begin{array}{c}.54 \\
(.22) \\
{[.17, .87]}\end{array}$ & $\begin{array}{c}.42 \\
(.00) \\
{[.41, .43]}\end{array}$ & $\begin{array}{c}.45 \\
(.00) \\
{[.45, .46]}\end{array}$ & $\begin{array}{c}.13 \\
(.06) \\
{[.05, .30]}\end{array}$ & $\begin{array}{c}.45 \\
(.03) \\
{[.39, .51]}\end{array}$ \\
\hline Difference & -.01 & -.02 & $-.03^{*}$ & $-.02 *$ & $.24 *$ & .05 \\
\hline \multicolumn{7}{|l|}{ Maternal age at birth } \\
\hline 25 or younger & $\begin{array}{c}.34 \\
(.01) \\
{[.32, .37]}\end{array}$ & $\begin{array}{c}.44 \\
(.11) \\
{[.25, .65]}\end{array}$ & $\begin{array}{c}.39 \\
(.00) \\
{[.38, .39]}\end{array}$ & $\begin{array}{c}.42 \\
(.00) \\
{[.41, .42]}\end{array}$ & $\begin{array}{c}.32 \\
(.04) \\
{[.25, .40]}\end{array}$ & $\begin{array}{c}.46 \\
(.02) \\
{[.41, .51]}\end{array}$ \\
\hline 26 or older & $\begin{array}{c}.36 \\
(.01) \\
{[.34, .38]}\end{array}$ & $\begin{array}{c}.55 \\
(.07) \\
{[.41, .68]}\end{array}$ & $\begin{array}{c}.40 \\
(.00) \\
{[.40, .41]}\end{array}$ & $\begin{array}{c}.45 \\
(.00) \\
{[.45, .46]}\end{array}$ & $\begin{array}{c}.30 \\
(.04) \\
{[.22, .62]}\end{array}$ & $\begin{array}{c}.55 \\
(.02) \\
{[.51, .60]}\end{array}$ \\
\hline Difference & -.01 & -.11 & $-.02 *$ & $-.03 *$ & .02 & -.09 \\
\hline
\end{tabular}

Note: Standard errors in parentheses and $95 \%$ confidence intervals in square brackets.

* indicates (a) if attached to the population-level estimate: that the sibling correlation in a country is statistically significantly different from the weighted average sibling correlation of all other countries at the $5 \%$ level; (b) if attached to the difference between social groups: that the conditional sibling

correlations at the group level are statistically significantly different from each other within the same country at the 5\% level. All differences are calculated using the unrounded sibling correlations.

Sources: Finland: Registers. Germany: Socio-Economic Panel Study (SOEP), v31.1 (DOI: 10.5684/soep.v31.1). Norway: Registers. Sweden: Registers.

United Kingdom: UK Household Longitudinal Study (Understanding Society), 8th edition (DOI: 10.5255/UKDA-SN-6614-9). United States: Panel Study of Income Dynamics (PSID). 
Tables S7-9. Sibling Similarity in Cognitive Skills, School Grades, and Educational Attainment, Normal-Based Confidence Intervals

Table S7. Sibling Correlations in Cognitive Skills

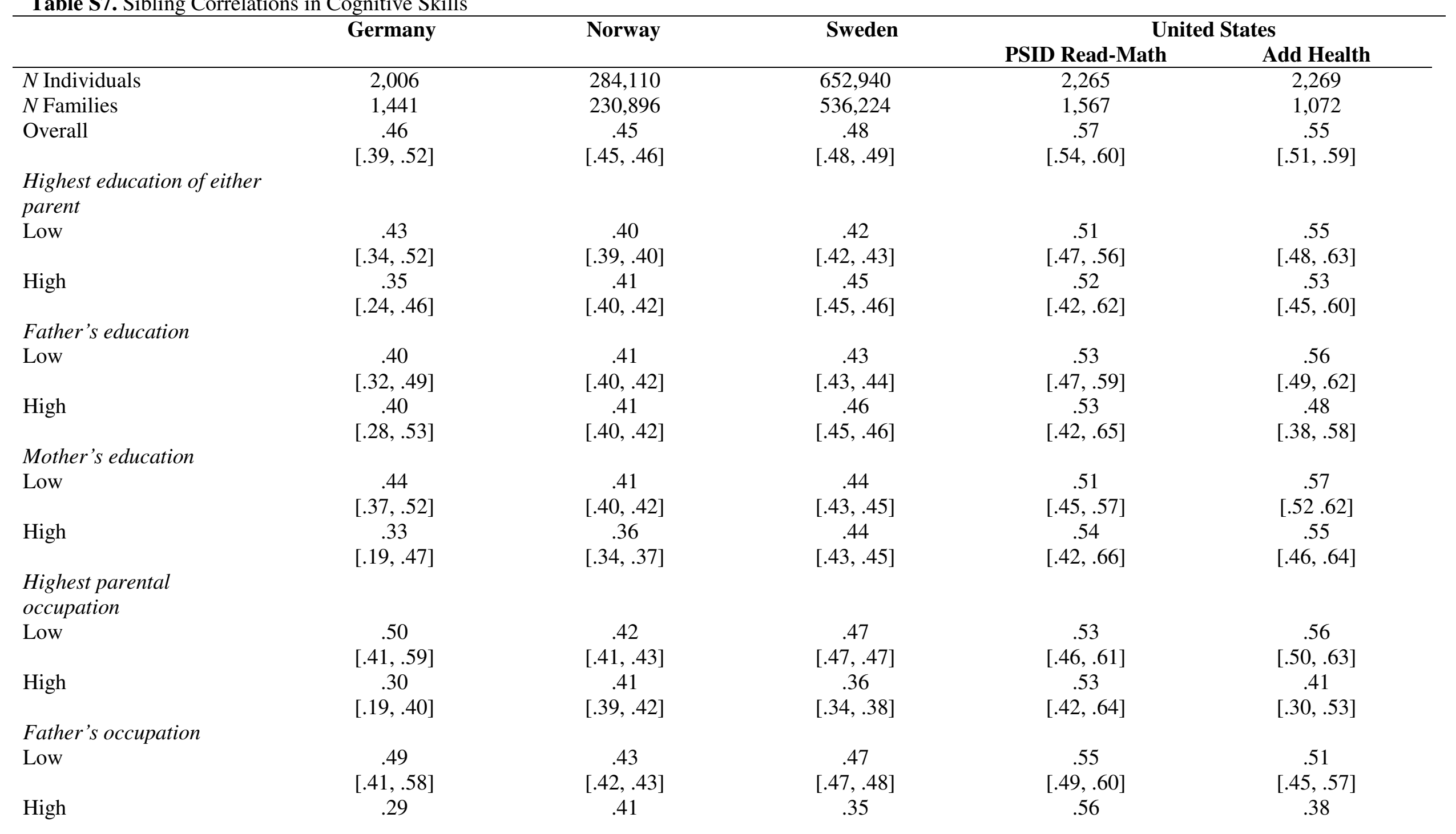


Mother's occupation

Low

High

Migration background

No migrant background

Migrant background

Family size

3 children and less

More than 3 children

Maternal age at birth

25 or younger

26 or older

$$
[.19, .40]
$$

$$
[.36, .55]
$$

$[.21, .43]$

$$
.40
$$

$[.32, .48]$

.47

$[.33, .60]$

$$
.47
$$

$[.41, .54]$

.31

$$
\text { [.03 .59] }
$$

$[.43, .67]$

.42

$[.33, .50]$
$[.40, .42]$

.44

$[.43, .44]$

.39

$[.37, .41]$

n/a

$\mathrm{n} / \mathrm{a}$

.44

$[.43, .45]$

.47

$[.46, .48]$
.44

$[.43, .45]$

.47

$[.46, .49]$
$[.33, .37]$

.47

$[.47, .48]$

.37

$[.34, .41]$

.47

$[.47, .48]$

.52

$[.51, .53]$

.47

$[.46, .47]$

.55

$[.54, .55]$

.46

$[.45, .47]$

.50

$[.49, .50]$
$[.42, .70]$

$[.23, .52]$

.57

$[.49, .62]$

$[.52, .62]$

.46

$[.33, .59]$

$[.38, .71]$

.46

.57

$[.52, .62]$

.58

$[.40, .53]$

.59

$[.50, .67]$

$.72]$

n/a

$\mathrm{n} / \mathrm{a}$

$\mathrm{n} / \mathrm{a}$

.57

$[.50, .65]$

.56

$[.50, .63]$

.54

$[.47, .61]$ 
Table S8. Sibling Correlations in School Grades

\begin{tabular}{|c|c|c|c|}
\hline & Norway & Sweden & United States \\
\hline$N$ Individuals & 403,661 & $1,026,673$ & 1,620 \\
\hline$N$ Families & 271,162 & 683,546 & 1,040 \\
\hline Overall & $\begin{array}{c}.48 \\
{[.47, .48]}\end{array}$ & $\begin{array}{c}.52 \\
{[.52, .52]}\end{array}$ & $\begin{array}{c}.42 \\
{[.36, .49]}\end{array}$ \\
\hline $\begin{array}{l}\text { Highest education of } \\
\text { either parent }\end{array}$ & & & \\
\hline Low & $\begin{array}{c}.42 \\
{[.41, .42]}\end{array}$ & $\begin{array}{c}.44 \\
{[.44, .45]}\end{array}$ & $\begin{array}{c}.30 \\
{[.18, .43]}\end{array}$ \\
\hline High & $\begin{array}{c}.39 \\
{[.39, .40]}\end{array}$ & $\begin{array}{c}.50 \\
{[.50, .50]}\end{array}$ & $\begin{array}{c}.51 \\
{[.40, .62]}\end{array}$ \\
\hline Father's education & & & \\
\hline Low & $\begin{array}{c}.43 \\
{[.43, .44]}\end{array}$ & $\begin{array}{c}.46 \\
{[.46, .47]}\end{array}$ & $\begin{array}{c}.32 \\
{[.21, .43]}\end{array}$ \\
\hline High & $\begin{array}{c}.39 \\
{[.38, .40]}\end{array}$ & $\begin{array}{c}.51 \\
{[.50, .51]}\end{array}$ & $\begin{array}{c}.56 \\
{[.43, .70]}\end{array}$ \\
\hline Mother's education & & & \\
\hline Low & $\begin{array}{c}.43 \\
{[.43, .44]}\end{array}$ & $\begin{array}{c}.46 \\
{[.45, .46]}\end{array}$ & $\begin{array}{c}.35 \\
{[.26, .44]}\end{array}$ \\
\hline High & $\begin{array}{c}.38 \\
{[.37, .39]}\end{array}$ & $\begin{array}{c}.50 \\
{[.50, .50]}\end{array}$ & $\begin{array}{c}.50 \\
{[.37, .63]}\end{array}$ \\
\hline $\begin{array}{l}\text { Highest parental } \\
\text { occupation }\end{array}$ & & & \\
\hline Low & $\begin{array}{c}.45 \\
{[.44, .45]}\end{array}$ & $\begin{array}{c}.50 \\
{[.50, .50]}\end{array}$ & $\begin{array}{c}.41 \\
{[.30, .52]}\end{array}$ \\
\hline High & $\begin{array}{c}.41 \\
{[.40, .42]}\end{array}$ & $\begin{array}{c}.47 \\
{[.47, .48]}\end{array}$ & $\begin{array}{c}.42 \\
{[.26, .59]}\end{array}$ \\
\hline Father's occupation & & & \\
\hline Low & $\begin{array}{c}.45 \\
{[.44, .45]}\end{array}$ & $\begin{array}{c}.51 \\
{[.50, .51]}\end{array}$ & $\begin{array}{c}.40 \\
{[.31, .49]}\end{array}$ \\
\hline High & $\begin{array}{c}.41 \\
{[.41, .42]}\end{array}$ & $\begin{array}{c}.48 \\
{[.47, .49]}\end{array}$ & $\begin{array}{c}.47 \\
{[.27, .67]}\end{array}$ \\
\hline $\begin{array}{l}\text { Mother's occupation } \\
\text { Low }\end{array}$ & .45 & .51 & .44 \\
\hline
\end{tabular}




\section{High}

Migration background

No migrant background

\section{Migrant background}

Family size

3 children and less

More than 3 children

Maternal age at birth

25 or younger

26 or older

(26 or older

Note: $95 \%$ confidence intervals in square brackets.

Sources: Norway: Registers. Sweden: Registers. United States: National Longitudinal Study of Adolescent to Adult Health (Add Health), Carolina Population

Center, University of North Carolina.
$[.45, .46]$

$[.39, .41]$

.47

$[.47, .48]$

.52

$[.50, .54]$

.48

$[.47, .48]$

.50

$[.49, .51]$

.45

$[.44, .45]$

.48

$[.48, .49]$
$[.51, .51]$

$[.47, .50]$

.38

$[.10, .67]$

.51

$[.50, .52]$

.51

$[.51, .52]$

$[.33, .51]$

.49

$[.35, .62]$

.52

$[.52, .52]$

.53

$\mathrm{n} / \mathrm{a}$

n/a

$[.52, .53]$

.47

$[.46, .47]$

.52

$[.52, .53]$

$[.33, .59]$
$[.34, .54]$

.46 
Table S9. Sibling Correlations in Final Educational Attainment (Years of Education)

\begin{tabular}{|c|c|c|c|c|c|c|}
\hline 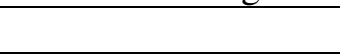 & Finland & Germany & Norway & Sweden & United Kingdom & United States \\
\hline$N$ Individuals & 79,467 & 1,034 & 643,701 & $2,302,256$ & 5,017 & 5,578 \\
\hline$N$ Families & 60,766 & 815 & 412,328 & $1,371,369$ & 4,131 & 2,866 \\
\hline Overall & $\begin{array}{c}.36 \\
{[.35, .37]}\end{array}$ & $\begin{array}{c}.51 \\
{[.42, .60]}\end{array}$ & $\begin{array}{c}.41 \\
{[.40, .41]}\end{array}$ & $\begin{array}{c}.44 \\
{[.44, .45]}\end{array}$ & $\begin{array}{c}.42 \\
{[.36, .48]}\end{array}$ & $\begin{array}{c}.51 \\
{[.48, .54]}\end{array}$ \\
\hline \multicolumn{7}{|l|}{$\begin{array}{l}\text { Highest education of } \\
\text { either parent }\end{array}$} \\
\hline Low & $\begin{array}{c}.31 \\
{[.29, .33]}\end{array}$ & $\begin{array}{c}.46 \\
{[.33, .58]}\end{array}$ & $\begin{array}{c}.33 \\
{[.33, .34]}\end{array}$ & $\begin{array}{c}.33 \\
{[.33, .34]}\end{array}$ & $\begin{array}{c}.18 \\
{[.07, .24]}\end{array}$ & $\begin{array}{c}.39 \\
{[.35, .43]}\end{array}$ \\
\hline High & $\begin{array}{c}.28 \\
{[.26, .30]}\end{array}$ & $\begin{array}{c}.35 \\
{[.19, .52]}\end{array}$ & $\begin{array}{c}.29 \\
{[.28, .29]}\end{array}$ & $\begin{array}{c}.43 \\
{[.43, .43]}\end{array}$ & $\begin{array}{c}.32 \\
{[.19, .44]}\end{array}$ & $\begin{array}{c}.51 \\
{[.45, .57]}\end{array}$ \\
\hline \multicolumn{7}{|l|}{ Father's education } \\
\hline Low & $\begin{array}{c}.31 \\
{[.30, .33]}\end{array}$ & $\begin{array}{c}.46 \\
{[.34, .59]}\end{array}$ & $\begin{array}{c}.35 \\
{[.34, .35]}\end{array}$ & $\begin{array}{c}.36 \\
{[.36, .37]}\end{array}$ & $\begin{array}{c}.24 \\
{[.14, .33]}\end{array}$ & $\begin{array}{c}.41 \\
{[.37, .45]}\end{array}$ \\
\hline High & $\begin{array}{c}.27 \\
{[.25, .29]}\end{array}$ & $\begin{array}{c}.29 \\
{[.10, .48]}\end{array}$ & $\begin{array}{c}.29 \\
{[.28, .29]}\end{array}$ & $\begin{array}{c}.44 \\
{[.43, .44]}\end{array}$ & $\begin{array}{c}.21 \\
{[.05, .38]}\end{array}$ & $\begin{array}{c}.50 \\
{[.43, .57]}\end{array}$ \\
\hline \multicolumn{7}{|l|}{ Mother's education } \\
\hline Low & $\begin{array}{c}.33 \\
{[.31, .34]}\end{array}$ & $\begin{array}{c}.50 \\
{[.40, .60]}\end{array}$ & $\begin{array}{c}.36 \\
{[.36, .36]}\end{array}$ & $\begin{array}{c}.37 \\
{[.37, .37]}\end{array}$ & $\begin{array}{c}.36 \\
{[.28, .44]}\end{array}$ & $\begin{array}{c}.45 \\
{[.41, .48]}\end{array}$ \\
\hline High & $\begin{array}{c}.27 \\
{[.24, .29]}\end{array}$ & $\begin{array}{c}.36 \\
{[.13, .59]}\end{array}$ & $\begin{array}{c}.28 \\
{[.27, .29]}\end{array}$ & $\begin{array}{c}.41 \\
{[.40, .41]}\end{array}$ & $\begin{array}{c}.37 \\
{[.26, .49]}\end{array}$ & $\begin{array}{c}.46 \\
{[.36, .56]}\end{array}$ \\
\hline \multicolumn{7}{|l|}{$\begin{array}{l}\text { Highest parental } \\
\text { occupation }\end{array}$} \\
\hline Low & $\begin{array}{c}.33 \\
{[.31, .34]}\end{array}$ & $\begin{array}{c}.46 \\
{[.31, .61]}\end{array}$ & $\begin{array}{c}.37 \\
{[.36, .37]}\end{array}$ & $\begin{array}{c}.42 \\
{[.42, .42]}\end{array}$ & $\begin{array}{c}.46 \\
{[.31, .61]}\end{array}$ & $\begin{array}{c}.48 \\
{[.45, .51]}\end{array}$ \\
\hline High & $\begin{array}{c}.29 \\
{[.27, .32]}\end{array}$ & $\begin{array}{c}.43 \\
{[.29, .57]}\end{array}$ & $\begin{array}{c}.35 \\
{[.34, .35]}\end{array}$ & $\begin{array}{c}.29 \\
{[.29, .30]}\end{array}$ & $\begin{array}{c}.35 \\
{[.23, .48]}\end{array}$ & $\begin{array}{c}.38 \\
{[.27, .50]}\end{array}$ \\
\hline \multicolumn{7}{|l|}{ Father's occupation } \\
\hline Low & $\begin{array}{c}.32 \\
{[.31, .34]}\end{array}$ & $\begin{array}{c}.42 \\
{[.26, .57]}\end{array}$ & $\begin{array}{c}.37 \\
{[.37, .38]}\end{array}$ & $\begin{array}{c}.43 \\
{[.43, .43]}\end{array}$ & $\begin{array}{c}.27 \\
{[.17, .37]}\end{array}$ & $\mathrm{n} / \mathrm{a}$ \\
\hline High & $\begin{array}{c}.29 \\
{[.27, .32]}\end{array}$ & $\begin{array}{c}.46 \\
{[.31, .60]}\end{array}$ & $\begin{array}{c}.35 \\
{[.34, .36]}\end{array}$ & $\begin{array}{c}.30 \\
{[.29, .31]}\end{array}$ & $\begin{array}{c}.28 \\
{[.14, .43]}\end{array}$ & $\mathrm{n} / \mathrm{a}$ \\
\hline $\begin{array}{l}\text { Mother's occupation } \\
\text { Low }\end{array}$ & .34 & .60 & .38 & .44 & .42 & $\mathrm{n} / \mathrm{a}$ \\
\hline
\end{tabular}




\begin{tabular}{|c|c|c|c|c|c|c|}
\hline High & $\begin{array}{c}{[.32, .35]} \\
.30 \\
{[.27, .33]}\end{array}$ & $\begin{array}{c}{[.49, .72]} \\
.35 \\
{[.15, .56]}\end{array}$ & $\begin{array}{c}{[.38, .38]} \\
.33 \\
{[.32, .34]}\end{array}$ & $\begin{array}{c}{[.43, .44]} \\
.26 \\
{[.25, .27]}\end{array}$ & $\begin{array}{c}{[.34, .51]} \\
.32 \\
{[.21, .44]}\end{array}$ & $\mathrm{n} / \mathrm{a}$ \\
\hline \multicolumn{7}{|l|}{ Migration } \\
\hline $\begin{array}{l}\text { background } \\
\text { No migrant } \\
\text { background }\end{array}$ & $\mathrm{n} / \mathrm{a}$ & $\begin{array}{c}.45 \\
{[.34, .55]}\end{array}$ & $\begin{array}{c}.40 \\
{[.40, .41]}\end{array}$ & $\begin{array}{c}.44 \\
{[.44, .45]}\end{array}$ & $\begin{array}{c}.38 \\
{[.27, .49]}\end{array}$ & $\mathrm{n} / \mathrm{a}$ \\
\hline Migrant background & $\mathrm{n} / \mathrm{a}$ & $\begin{array}{c}.70 \\
{[.57, .84]}\end{array}$ & $\begin{array}{c}.43 \\
{[.41, .45]}\end{array}$ & $\begin{array}{c}.43 \\
{[.43, .44]}\end{array}$ & $\begin{array}{c}.23 \\
{[.12, .34]}\end{array}$ & $\mathrm{n} / \mathrm{a}$ \\
\hline Family size & & & & & & \\
\hline 3 children and less & $\begin{array}{c}.35 \\
{[.34, .37]}\end{array}$ & $\begin{array}{c}.50 \\
{[.41, .59]}\end{array}$ & $\begin{array}{c}.39 \\
{[.38, .39]}\end{array}$ & $\begin{array}{c}.44 \\
{[.43, .44]}\end{array}$ & $\begin{array}{c}.48 \\
{[.41, .54]}\end{array}$ & $\begin{array}{c}.51 \\
{[.47, .55]}\end{array}$ \\
\hline More than 3 children & $\begin{array}{c}.37 \\
{[.34, .39]}\end{array}$ & $\begin{array}{c}.54 \\
{[.11, .97]}\end{array}$ & $\begin{array}{c}.42 \\
{[.41, .42]}\end{array}$ & $\begin{array}{c}.45 \\
{[.45, .45]}\end{array}$ & $\begin{array}{c}.13 \\
{[.01, .25]}\end{array}$ & $\begin{array}{c}.47 \\
{[.42, .52]}\end{array}$ \\
\hline Maternal age at birth & & & & & & \\
\hline 25 or younger & $\begin{array}{c}.34 \\
{[.32, .36]}\end{array}$ & $\begin{array}{c}.43 \\
{[.22, .63]}\end{array}$ & $\begin{array}{c}.39 \\
{[.38, .39]}\end{array}$ & $\begin{array}{c}.42 \\
{[.41, .42]}\end{array}$ & $\begin{array}{c}.45 \\
{[.37, .54]}\end{array}$ & $\begin{array}{c}.47 \\
{[.43, .52]}\end{array}$ \\
\hline 26 or older & $\begin{array}{c}.35 \\
{[.34, .37]}\end{array}$ & $\begin{array}{c}.53 \\
{[.40, .66]}\end{array}$ & $\begin{array}{c}.41 \\
{[.40, .41]}\end{array}$ & $\begin{array}{c}.46 \\
{[.46, .46]}\end{array}$ & $\begin{array}{c}.37 \\
{[.28, .46]}\end{array}$ & $\begin{array}{c}.55 \\
{[.51, .59]}\end{array}$ \\
\hline
\end{tabular}

Sources: Finland: Registers. Germany: Socio-Economic Panel Study (SOEP), v31.1 (DOI: 10.5684/soep.v31.1). Norway: Registers. Sweden: Registers.

United Kingdom: UK Household Longitudinal Study (Understanding Society), 8th edition (DOI: 10.5255/UKDA-SN-6614-9). United States: Panel Study of Income Dynamics (PSID). 
Tables S10-12. Sibling Similarity in Cognitive Skills, School Grades, and Educational Attainment, Normal-Based Confidence Intervals, Robustness Check Using Only Siblings

Table S10. Sibling Correlations in Cognitive Skills

\begin{tabular}{|c|c|c|c|c|c|}
\hline & \multirow[t]{2}{*}{ Germany } & \multirow[t]{2}{*}{ Norway } & \multirow[t]{2}{*}{ Sweden } & \multicolumn{2}{|c|}{ United States } \\
\hline & & & & PSID Read-Math & Add Health \\
\hline$N$ Individuals & 1,036 & 101,220 & 223,159 & 1,396 & 2,231 \\
\hline$N$ Families & 471 & 48,006 & 106,443 & 698 & 1,034 \\
\hline \multirow[t]{2}{*}{ Overall } & .44 & .45 & .49 & .57 & .54 \\
\hline & {$[.37, .51]$} & {$[.45, .46]$} & {$[.49, .50]$} & {$[.52, .62]$} & {$[.50, .58]$} \\
\hline \multicolumn{6}{|c|}{$\begin{array}{l}\text { Highest education of either } \\
\text { parent }\end{array}$} \\
\hline \multirow[t]{2}{*}{ Low } & .42 & .40 & .42 & .51 & .54 \\
\hline & {$[.33, .51]$} & {$[.39, .40]$} & {$[.42, .43]$} & {$[.44, .58]$} & {$[.46, .62]$} \\
\hline \multirow[t]{2}{*}{ High } & .35 & .41 & .45 & .46 & .53 \\
\hline & {$[.24, .46]$} & {$[.40, .42]$} & {$[.45, .46]$} & {$[.35, .57]$} & {$[.45, .60]$} \\
\hline \multicolumn{6}{|c|}{ Father's education } \\
\hline \multirow[t]{2}{*}{ Low } & .39 & .41 & .43 & .53 & .55 \\
\hline & {$[.31 .48]$} & {$[.40, .42]$} & {$[.43, .44]$} & {$[.47, .60]$} & {$[.48, .61]$} \\
\hline \multirow[t]{2}{*}{ High } & .39 & .42 & .46 & .47 & .47 \\
\hline & {$[.27, .52]$} & {$[.41, .43]$} & {$[.45, .47]$} & {$[.35, .59]$} & {$[.37, .57]$} \\
\hline \multicolumn{6}{|c|}{ Mother's education } \\
\hline \multirow[t]{2}{*}{ Low } & .43 & .41 & .44 & .51 & .56 \\
\hline & {$[.35, .51]$} & {$[.40, .42]$} & {$[.44, .45]$} & {$[.45, .57]$} & {$[.51, .62]$} \\
\hline \multirow[t]{2}{*}{ High } & .32 & .35 & .44 & .46 & .54 \\
\hline & {$[.18, .46]$} & {$[.34, .37]$} & {$[.43, .45]$} & {$[.34, .59]$} & {$[.45, .63]$} \\
\hline \multicolumn{6}{|c|}{ Highest parental occupation } \\
\hline \multirow[t]{2}{*}{ Low } & .49 & .42 & .48 & .54 & .56 \\
\hline & {$[.39, .58]$} & {$[.41, .43]$} & {$[.47, .48]$} & {$[.46, .62]$} & {$[.50, .63]$} \\
\hline \multirow[t]{2}{*}{ High } & .29 & .41 & .36 & .49 & .41 \\
\hline & {$[.19, .40]$} & {$[.40, .42]$} & {$[.34, .38]$} & {$[.37, .60]$} & {$[.30, .53]$} \\
\hline \multicolumn{6}{|c|}{ Father's occupation } \\
\hline \multirow[t]{2}{*}{ Low } & .48 & .42 & .48 & .55 & .51 \\
\hline & {$[.39, .58]$} & {$[.42, .43]$} & {$[.48, .48]$} & {$[.49, .61]$} & {$[.45, .57]$} \\
\hline High & .29 & .41 & .35 & .47 & .38 \\
\hline
\end{tabular}




\begin{tabular}{|c|c|c|c|c|c|}
\hline & {$[.18, .40]$} & {$[.40, .43]$} & {$[.33, .37]$} & {$[.32, .62]$} & {$[.23, .52]$} \\
\hline \multicolumn{6}{|l|}{ Mother's occupation } \\
\hline \multirow[t]{2}{*}{ Low } & .43 & .44 & .48 & .55 & .57 \\
\hline & {$[.33, .53]$} & {$[.43, .45]$} & {$[.48, .49]$} & {$[.48, .62]$} & {$[.52, .62]$} \\
\hline \multirow[t]{2}{*}{ High } & .32 & .39 & .37 & .47 & .55 \\
\hline & {$[.21, .43]$} & {$[.37, .41]$} & {$[.34, .40]$} & {$[.34, .61]$} & {$[.38, .71]$} \\
\hline \multicolumn{6}{|l|}{ Migration background } \\
\hline \multirow[t]{2}{*}{ No migrant background } & .38 & $\mathrm{n} / \mathrm{a}$ & .48 & .56 & .46 \\
\hline & {$[.30, .46]$} & & {$[.47, .48]$} & {$[.51, .62]$} & {$[.40, .53]$} \\
\hline \multirow[t]{2}{*}{ Migrant background } & .44 & $\mathrm{n} / \mathrm{a}$ & .54 & .59 & .57 \\
\hline & {$[.29, .58]$} & & {$[.52, .55]$} & {$[.44, .74]$} & {$[.49, .65]$} \\
\hline \multicolumn{6}{|l|}{ Family size } \\
\hline \multirow[t]{2}{*}{3 children and less } & .46 & .44 & .47 & $\mathrm{n} / \mathrm{a}$ & $\mathrm{n} / \mathrm{a}$ \\
\hline & {$[.39, .53]$} & {$[.43, .45]$} & {$[.47, .48]$} & & \\
\hline \multirow[t]{2}{*}{ More than 3 children } & .25 & .47 & .56 & $\mathrm{n} / \mathrm{a}$ & $\mathrm{n} / \mathrm{a}$ \\
\hline & {$[-.00, .50]$} & {$[.46, .49]$} & {$[.55, .56]$} & & \\
\hline \multicolumn{6}{|l|}{ Maternal age at birth } \\
\hline \multirow[t]{2}{*}{25 or younger } & .53 & .44 & .47 & .58 & .57 \\
\hline & {$[.41, .66]$} & {$[.43, .45]$} & {$[.46, .48]$} & {$[.49, .66]$} & {$[.50, .63]$} \\
\hline \multirow[t]{2}{*}{26 or older } & .41 & .48 & .51 & .52 & .54 \\
\hline & {$[.31, .50]$} & {$[.46, .49]$} & {$[.50, .51]$} & {$[.45, .60]$} & {$[.46, .62]$} \\
\hline
\end{tabular}

Sources: Germany: Socio-Economic Panel Study (SOEP), v31.1 (DOI: 10.5684/soep.v31.1). Norway: Registers. Sweden: Registers. United States: Panel Study of Income Dynamics (PSID) and National Longitudinal Study of Adolescent to Adult Health (Add Health), Carolina Population Center, University of North Carolina. 
Table S11. Sibling Correlations in School Grades

\begin{tabular}{|c|c|c|c|}
\hline (2) & Norway & Sweden & United States \\
\hline$N$ Individuals & 246,600 & 625,421 & 1,112 \\
\hline$N$ Families & 114,101 & 282,294 & 532 \\
\hline Overall & $\begin{array}{c}.47 \\
{[.47, .47]}\end{array}$ & $\begin{array}{c}.51 \\
{[.50, .51]}\end{array}$ & $\begin{array}{c}.42 \\
{[.36, .49]}\end{array}$ \\
\hline \multicolumn{4}{|l|}{$\begin{array}{l}\text { Highest education of } \\
\text { either parent }\end{array}$} \\
\hline Low & $\begin{array}{c}.41 \\
{[.40, .41]}\end{array}$ & $\begin{array}{c}.43 \\
{[.43, .44]}\end{array}$ & $\begin{array}{c}.30 \\
{[.17, .42]}\end{array}$ \\
\hline High & $\begin{array}{c}.38 \\
{[.37, .39]}\end{array}$ & $\begin{array}{c}.49 \\
{[.48, .49]}\end{array}$ & $\begin{array}{c}.50 \\
{[.38, .62]}\end{array}$ \\
\hline \multicolumn{4}{|l|}{ Father's education } \\
\hline Low & $\begin{array}{c}.43 \\
{[.42, .43]}\end{array}$ & $\begin{array}{c}.45 \\
{[.45, .45]}\end{array}$ & $\begin{array}{c}.32 \\
{[.23, .41]}\end{array}$ \\
\hline High & $\begin{array}{c}.38 \\
{[.37, .39]}\end{array}$ & $\begin{array}{c}.50 \\
{[.49, .50]}\end{array}$ & $\begin{array}{c}.55 \\
{[.40, .69]}\end{array}$ \\
\hline \multicolumn{4}{|l|}{ Mother's education } \\
\hline Low & $\begin{array}{c}.43 \\
{[.42, .43]}\end{array}$ & $\begin{array}{c}.45 \\
{[.45, .45]}\end{array}$ & $\begin{array}{c}.35 \\
{[.26, .45]}\end{array}$ \\
\hline High & $\begin{array}{c}.36 \\
{[.35, .37]}\end{array}$ & $\begin{array}{c}.49 \\
{[.49, .49]}\end{array}$ & $\begin{array}{c}.50 \\
{[.36, .64]}\end{array}$ \\
\hline \multicolumn{4}{|l|}{$\begin{array}{l}\text { Highest parental } \\
\text { occupation }\end{array}$} \\
\hline Low & $\begin{array}{c}.44 \\
{[.44, .45]}\end{array}$ & $\begin{array}{c}.49 \\
{[.49, .49]}\end{array}$ & $\begin{array}{c}.42 \\
{[.31, .53]}\end{array}$ \\
\hline High & $\begin{array}{c}.40 \\
{[.39, .41]}\end{array}$ & $\begin{array}{c}.47 \\
{[.46, .48]}\end{array}$ & $\begin{array}{c}.41 \\
{[.24, .58]}\end{array}$ \\
\hline Father's occupation & & & \\
\hline Low & $\begin{array}{c}.44 \\
{[.44, .45]}\end{array}$ & $\begin{array}{c}.49 \\
{[.49, .50]}\end{array}$ & $\begin{array}{c}.40 \\
{[.30, .49]}\end{array}$ \\
\hline High & $\begin{array}{c}.40 \\
{[.39, .41]}\end{array}$ & $\begin{array}{c}.47 \\
{[.46, .48]}\end{array}$ & $\begin{array}{c}.46 \\
{[.26, .67]}\end{array}$ \\
\hline $\begin{array}{l}\text { Mother's occupation } \\
\text { Low }\end{array}$ & .45 & .50 & .44 \\
\hline
\end{tabular}




\begin{tabular}{|c|c|c|c|}
\hline High & $\begin{array}{c}{[.44, .45]} \\
.39 \\
{[.38, .40]}\end{array}$ & $\begin{array}{c}{[.50, .50]} \\
.48 \\
{[.46, .49]}\end{array}$ & $\begin{array}{c}{[.36, .52]} \\
.37 \\
{[.08, .66]}\end{array}$ \\
\hline \multicolumn{4}{|l|}{ Migration background } \\
\hline No migrant background & $\begin{array}{c}.46 \\
{[.46, .47]} \\
.51 \\
{[.49, .53]}\end{array}$ & $\begin{array}{c}.50 \\
{[.50, .50]} \\
.51 \\
{[.50, .52]}\end{array}$ & $\begin{array}{c}.41 \\
{[.32, .50]} \\
.49 \\
{[.35, .63]}\end{array}$ \\
\hline \multicolumn{4}{|l|}{ Family size } \\
\hline 2-3 children & $\begin{array}{c}.45 \\
{[.44, . .45]}\end{array}$ & $\begin{array}{c}.50 \\
{[.50, .50]}\end{array}$ & $\mathrm{n} / \mathrm{a}$ \\
\hline More than 3 children & $\begin{array}{c}.49 \\
{[.49, .50]}\end{array}$ & $\begin{array}{c}.53 \\
{[.52, .53]}\end{array}$ & $\mathrm{n} / \mathrm{a}$ \\
\hline \multicolumn{4}{|l|}{ Maternal age at birth } \\
\hline 25 or younger & $\begin{array}{c}.43 \\
{[.42, .44]}\end{array}$ & $\begin{array}{c}.46 \\
{[.45, .46]}\end{array}$ & $\begin{array}{c}.44 \\
{[.33, .54]}\end{array}$ \\
\hline 26 or older & $\begin{array}{c}.46 \\
{[.45, .47]}\end{array}$ & $\begin{array}{c}.52 \\
{[.51, .52]}\end{array}$ & $\begin{array}{c}.45 \\
{[.32, .59]}\end{array}$ \\
\hline
\end{tabular}

Note: $95 \%$ confidence intervals in square brackets.

Sources: Norway: Registers. Sweden: Registers. United States: National Longitudinal Study of Adolescent to Adult Health (Add Health), Carolina Population

Center, University of North Carolina. 
Table S12. Sibling Correlations in Final Educational Attainment (Years of Education)

\begin{tabular}{|c|c|c|c|c|c|c|}
\hline 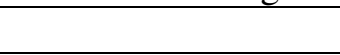 & Finland & Germany & Norway & Sweden & United Kingdom & United States \\
\hline$N$ Individuals & 35,740 & 411 & 421,692 & $1,646,003$ & 2,363 & 4,320 \\
\hline$N$ Families & 17,039 & 192 & 190,319 & 715,116 & 1,491 & 1,608 \\
\hline Overall & $\begin{array}{c}.36 \\
{[.35, .38]}\end{array}$ & $\begin{array}{c}.53 \\
{[.44, .63]}\end{array}$ & $\begin{array}{c}.40 \\
{[.40, .41]}\end{array}$ & $\begin{array}{c}.44 \\
{[.44, .45]}\end{array}$ & $\begin{array}{c}.32 \\
{[.26, .37]}\end{array}$ & $\begin{array}{c}.50 \\
{[.48, .53]}\end{array}$ \\
\hline \multicolumn{7}{|l|}{$\begin{array}{l}\text { Highest education of } \\
\text { either parent }\end{array}$} \\
\hline Low & $\begin{array}{c}.31 \\
{[.29, .32]}\end{array}$ & $\begin{array}{c}.48 \\
{[.34, .62]}\end{array}$ & $\begin{array}{c}.33 \\
{[.33, .33]}\end{array}$ & $\begin{array}{c}.33 \\
{[.33, .33]}\end{array}$ & $\begin{array}{c}.16 \\
{[.06, .26]}\end{array}$ & $\begin{array}{c}.39 \\
{[.35, .43]}\end{array}$ \\
\hline High & $\begin{array}{c}.28 \\
{[.26, .30]}\end{array}$ & $\begin{array}{c}.38 \\
{[.20, .56]}\end{array}$ & $\begin{array}{c}.28 \\
{[.27, .29]}\end{array}$ & $\begin{array}{c}.42 \\
{[.42, .42]}\end{array}$ & $\begin{array}{c}.28 \\
{[.16, .40]}\end{array}$ & $\begin{array}{c}.51 \\
{[.44, .57]}\end{array}$ \\
\hline \multicolumn{7}{|l|}{ Father's education } \\
\hline Low & $\begin{array}{c}.31 \\
{[.30, .33]}\end{array}$ & $\begin{array}{c}.47 \\
{[.33, .60]}\end{array}$ & $\begin{array}{c}.34 \\
{[.34, .35]}\end{array}$ & $\begin{array}{c}.36 \\
{[.36, .36]}\end{array}$ & $\begin{array}{c}.21 \\
{[.13, .30]}\end{array}$ & $\begin{array}{c}.41 \\
{[.37, .45]}\end{array}$ \\
\hline High & $\begin{array}{c}.27 \\
{[.25, .29]}\end{array}$ & $\begin{array}{c}.31 \\
{[.11, .51]}\end{array}$ & $\begin{array}{c}.28 \\
{[.27, .29]}\end{array}$ & $\begin{array}{c}.43 \\
{[.43, .43]}\end{array}$ & $\begin{array}{c}.21 \\
{[.05, .36]}\end{array}$ & $\begin{array}{c}.50 \\
{[.43, .57]}\end{array}$ \\
\hline \multicolumn{7}{|l|}{ Mother's education } \\
\hline Low & $\begin{array}{c}.33 \\
{[.31, .34]}\end{array}$ & $\begin{array}{c}.53 \\
{[.42, .64]}\end{array}$ & $\begin{array}{c}.36 \\
{[.35, .36]}\end{array}$ & $\begin{array}{c}.37 \\
{[.37, .37]}\end{array}$ & $\begin{array}{c}.28 \\
{[.21, .34]}\end{array}$ & $\begin{array}{c}.44 \\
{[.41, .48]}\end{array}$ \\
\hline High & $\begin{array}{c}.27 \\
{[.24, .29]}\end{array}$ & $\begin{array}{c}.39 \\
{[.14, .64]}\end{array}$ & $\begin{array}{c}.27 \\
{[.26, .28]}\end{array}$ & $\begin{array}{c}.40 \\
{[.39, .40]}\end{array}$ & $\begin{array}{c}.36 \\
{[.24, .47]}\end{array}$ & $\begin{array}{c}.44 \\
{[.35, .54]}\end{array}$ \\
\hline \multicolumn{7}{|l|}{$\begin{array}{l}\text { Highest parental } \\
\text { occupation }\end{array}$} \\
\hline Low & $\begin{array}{c}.33 \\
{[.31, .34]}\end{array}$ & $\begin{array}{c}.48 \\
{[.32, .65]}\end{array}$ & $\begin{array}{c}.36 \\
{[.36, .37]}\end{array}$ & $\begin{array}{c}.42 \\
{[.42, .42]}\end{array}$ & $\begin{array}{c}.39 \\
{[.24, .54]}\end{array}$ & $\begin{array}{c}.48 \\
{[.44, .51]}\end{array}$ \\
\hline High & $\begin{array}{c}.29 \\
{[.27, .32]}\end{array}$ & $\begin{array}{c}.43 \\
{[.29, .58]}\end{array}$ & $\begin{array}{c}.34 \\
{[.34, .35]}\end{array}$ & $\begin{array}{c}.29 \\
{[.28, .30]}\end{array}$ & $\begin{array}{c}.30 \\
{[.18, .42]}\end{array}$ & $\begin{array}{c}.37 \\
{[.26, .48]}\end{array}$ \\
\hline \multicolumn{7}{|l|}{ Father's occupation } \\
\hline Low & $\begin{array}{c}.32 \\
{[.30, .34]}\end{array}$ & $\begin{array}{c}.44 \\
{[.27, .61]}\end{array}$ & $\begin{array}{c}.37 \\
{[.36, .37]}\end{array}$ & $\begin{array}{c}.43 \\
{[.43, .43]}\end{array}$ & $\begin{array}{c}.24 \\
{[.15, .34]}\end{array}$ & $\mathrm{n} / \mathrm{a}$ \\
\hline High & $\begin{array}{c}.29 \\
{[.27, .32]}\end{array}$ & $\begin{array}{c}.45 \\
{[.31, .60]}\end{array}$ & $\begin{array}{c}.35 \\
{[.34, .36]}\end{array}$ & $\begin{array}{c}.29 \\
{[.28, .30]}\end{array}$ & $\begin{array}{c}.25 \\
{[.11, .38]}\end{array}$ & $\mathrm{n} / \mathrm{a}$ \\
\hline $\begin{array}{l}\text { Mother's occupation } \\
\text { Low }\end{array}$ & .34 & .62 & .38 & .44 & .35 & $\mathrm{n} / \mathrm{a}$ \\
\hline
\end{tabular}




\begin{tabular}{|c|c|c|c|c|c|c|}
\hline \multirow[b]{2}{*}{ High } & {$[.32, .35]$} & {$[.49, .75]$} & {$[.37, .38]$} & {$[.43, .44]$} & {$[.26, .43]$} & \multirow[b]{2}{*}{$\mathrm{n} / \mathrm{a}$} \\
\hline & .29 & .36 & .33 & .25 & .29 & \\
\hline \multicolumn{7}{|l|}{$\begin{array}{l}\text { Migration } \\
\text { hackoround }\end{array}$} \\
\hline background & & & & & & \\
\hline No migrant & $\mathrm{n} / \mathrm{a}$ & .47 & .40 & .44 & .30 & $\mathrm{n} / \mathrm{a}$ \\
\hline background & & {$[.35, .58]$} & {$[.40, .41]$} & {$[.44, .45]$} & {$[.20, .40]$} & \\
\hline Migrant background & $\mathrm{n} / \mathrm{a}$ & $\begin{array}{c}.72 \\
{[.56, .87]}\end{array}$ & $\begin{array}{c}.42 \\
{[.39, .44]}\end{array}$ & $\begin{array}{c}.43 \\
{[.43, .44]}\end{array}$ & $\begin{array}{c}.22 \\
{[.11, .33]}\end{array}$ & $\mathrm{n} / \mathrm{a}$ \\
\hline \multicolumn{7}{|l|}{ Family size } \\
\hline 3 children and less & $\begin{array}{c}.36 \\
{[.34, .37]}\end{array}$ & $\begin{array}{c}.52 \\
{[.42, .62]}\end{array}$ & $\begin{array}{c}.39 \\
{[.38, .39]}\end{array}$ & $\begin{array}{c}.43 \\
{[.43, .44]}\end{array}$ & $\begin{array}{c}.37 \\
{[.31, .43]}\end{array}$ & $\begin{array}{c}.50 \\
{[.47, .54]}\end{array}$ \\
\hline More than 3 children & $\begin{array}{c}.37 \\
{[.34, .39]}\end{array}$ & $\begin{array}{c}.54 \\
{[.11, .97]}\end{array}$ & $\begin{array}{c}.42 \\
{[.41, .43]}\end{array}$ & $\begin{array}{c}.45 \\
{[.45, .46]}\end{array}$ & $\begin{array}{c}.13 \\
{[.01, .25]}\end{array}$ & $\begin{array}{c}.45 \\
{[.39, .51]}\end{array}$ \\
\hline Maternal age at birth & & & & & & \\
\hline 25 or younger & $\begin{array}{c}.34 \\
{[32, .37]}\end{array}$ & $\begin{array}{c}.44 \\
{[.23, .65]}\end{array}$ & $\begin{array}{c}.39 \\
{[.38, .39]}\end{array}$ & $\begin{array}{c}.42 \\
{[.41, .42]}\end{array}$ & $\begin{array}{c}.32 \\
{[.25, .40]}\end{array}$ & $\begin{array}{c}.46 \\
{[.42, .51]}\end{array}$ \\
\hline 26 or older & $\begin{array}{c}.36 \\
{[.34, .37]}\end{array}$ & $\begin{array}{c}.55 \\
{[.41, .69]}\end{array}$ & $\begin{array}{c}.40 \\
{[.40, .41]}\end{array}$ & $\begin{array}{c}.45 \\
{[.45, .46]}\end{array}$ & $\begin{array}{c}.30 \\
{[.22, .39]}\end{array}$ & $\begin{array}{c}.55 \\
{[.51, .60]}\end{array}$ \\
\hline
\end{tabular}

Sources: Finland: Registers. Germany: Socio-Economic Panel Study (SOEP), v31.1 (DOI: 10.5684/soep.v31.1). Norway: Registers. Sweden: Registers.

United Kingdom: UK Household Longitudinal Study (Understanding Society), 8th edition (DOI: 10.5255/UKDA-SN-6614-9). United States: Panel Study of Income Dynamics (PSID). 